\title{
KEPEMIMPINAN PENDETA PEREMPUAN DI LINGKUP SINODAL GEREJA PROTESTAN DI INDONESIA BAGIAN BARAT (GPIB): SUATU TINJAUAN TEOLOGIS-PEDAGOGIS
}

\author{
Nova Linda Romeantenan ${ }^{1}$ \\ Desi Sianipar \\ Universitas Kristen Indonesia \\ novalinda55@gmail.com \\ Desi.sianipar07@gmail.com
}

\begin{abstract}
Abstrak
Kepemimpinan sangat penting bagi kelangsungan pelayanan gereja. Kepemimpinan yang baik akan sangat bergantung pada tingkat komitmen, konsistensi dan kesediaan menerima konsekuensi pelayanan dalam kerendahan hati, sehingga menyebabkan mereka yang dipimpin melakukan serangkaian tindakan dengan penuh kesadaran guna mencapai tujuan yang telah disepakati. Kepemimpinan pendeta perempuan secara teoritis diartikan sebagai kemampuan seorang pendeta perempuan dalam menggerakkan atau mempengaruhi jemaat dan dirinya menuju suatu tujuan dengan visi tertentu, dan mentransformasi komunitasnya sehingga kondisinya semakin baik.

Penelitian dilaksanakan di kantor Majelis Sinode GPIB dengan teknik pengumpulan data deskriptif kualitatif melalui studi kepustakaan, wawancara, observasi, dan dokumentasi. Penelitian ini bertujuan untuk melihat keadaan yang sebenarnya dari kepemimpinan pendeta perempuan di lingkup sinodal GPIB. Sampel yang digunakan adalah model sampel bertujuan (purposive sampling). Informan dalam penelitian ini berjumlah 13 orang yang terdiri dari 7 orang fungsionaris Majelis Sinode dan 6 orang perangkat-perangkat Majelis Sinode GPIB, yang terdiri dari 4 pendeta perempuan, 1 penatua perempuan dan 1 pendeta laki-laki. Kemudian dilakukan analisis untuk melihat kendala dan cara pendekatan agar dengan tinjauan teologis-pedagogis ini dapat mencapai tujuan yang diharapkan.

Dari hasil penelitian ini, ditemukan bahwa kepemimpinan pendeta perempuan di GPIB dibangun berdasarkan Alkitab di mana perempuan dan laki-laki diciptakan segambar dengan Allah (Kej. 1:27). Artinya, laki-laki dan perempuan adalah gambar Allah yang diciptakan setara dan sederajat. Pendeta perempuan dan pendeta laki-laki tidak ada perbedaan dalam hal kepemimpinan di lingkup sinodal GPIB. GPIB sebagai lembaga sangat terbuka dan memberikan peluang yang sangat luas kepada pendeta perempuan untuk membangun dan mengembangkan dirinya melalui pendidikan, pelatihan dan pembinaan. GPIB sebagai lembaga sudah sangat maju dan terbuka
\end{abstract}

${ }^{1}$ Alumni Prodi Magister Pendidikan Agama Kristen UKI Angkatan 2018 dan Pendeta GPIB 
memberikan peluang untuk perempuan memimpin di lingkup struktural sinodal GPIB. Pendeta perempuan sebagai pelaku sejarah telah berperan di ruang publik dan domestik. Peran domestik dan peran publik sudah ikut mempengaruhi perubahan pada kepemimpinan di GPIB. Meskipun dalam kepemimpinan pendeta perempuan banyak tantangan, tetapi pendeta perempuan GPIB telah mempengaruhi gerak menggereja menurut konteksnya.

Kata kunci: kepemimpinan, pendeta perempuan, tinjauan teologis-pedagogis.

\section{Pendahuluan}

Sejak awal kehidupan manusia, secara alamiah masyarakat telah membedakan kepemimpinan laki-laki dan kepemimpinan perempuan. Dalam banyak hal laki-laki ditempatkan pada kedudukan yang lebih unggul dan menang atas perempuan yang sering dianggap lemah. ${ }^{1}$ Laki-laki dianggap lebih cocok dengan pekerjaan di luar rumah (publik), sementara perempuan dianggap lebih cocok dengan pekerjaan rumah tangga (domestik). Dengan kata lain, laki-laki diberikan peluang yang lebih besar daripada perempuan. Itulah yang disebut budaya partriarkat.

Budaya patriarkat di tengah masyarakat ikut memberi andil dalam menempatkan laki-laki dan perempuan pada peran yang berbeda. Kesempatan promosi yang diberikan kepada perempuan juga sering tidak setara dengan laki-laki. Perempuan dianggap kurang cocok sebagai pemimpin. Sering terjadi benturan antara kewajiban perempuan di tempat bekerja dan peran mereka sebagai ibu dan istri di rumah. Sebab bagi perempuan yang telah berumahtangga dan bekerja, mereka juga memiliki kewajiban untuk mengurus rumah tangganya secara penuh seorang diri. Dapat dikatakan, masyarakat masih memiliki

\footnotetext{
${ }^{1}$ Kamila Bashin, Menggugat Patriarki:

Pengantar tentang Persoalan Dominasi terhadap Kaum Perempuan (Yogyakarta: Bentang Budaya, 1996), 27.
}

pemahaman yang kuat bahwa tugas utama seorang perempuan adalah melayani laki-laki. Dengan demikian pengaruh stereotipe yang dilekatkan pada perempuan telah berakibat pada pembatasan yang menyulitkan dan merugikan perempuan.

Dalam gereja masih terdapat perbedaan peran kepemimpinan antara laki-laki dan perempuan, walaupun sebenarnya misi gereja adalah memberitakan Injil dan melayani sesama menurut pola hidup Tuhan Yesus tanpa membedakan jenis kelamin. Semua orang Kristen dipanggil untuk melayani, bukan dilayani. Meskipun dalam kenyataannya perempuan sering berperan seperti Marta (Luk. 10:38-42) yang secara langsung atau tidak langsung sangat membantu proses pewartaan dan perkembangan gereja, namun keterlibatan mereka cenderung dibatasi. Yang memegang otoritas sebagai pejabat gereja umumnya adalah laki-laki. ${ }^{2}$ Akibatnya, kaum perempuan tidak mendapat kesempatan untuk berkarya sesuai karisma dan kemampuan mereka. Bahkan mereka dianggap kelas dua dan didiskriminasi. Banyak perempuan yang berpotensi di gereja tidak memperoleh kesempatan yang sama dengan pendeta laki-laki

\footnotetext{
${ }^{2}$ Anne Hemmes, Perubahan Peran Lakilaki dan Wanita dalam Gereja dan Masyarakat (Jakarta: BPK Gunung Mulia dan Yogyakarta: Kanisius, 1992), 127-128.
} 
dalam melaksanakan tugas pelayanan, terutama sebagai pemimpin. Padahal kaum perempuan dihadirkan Tuhan untuk berjalan bersama dengan lakilaki. Kaum perempuan juga dihadirkan Tuhan untuk membina masa depan umat Tuhan dalam menghadapi tantangan.

Permasalahan kepemimpinan perempuan di gereja terus berlanjut dan hangat dibicarakan hingga saat ini. Keinginan kaum perempuan untuk menjadi pemimpin gereja dianggap sebagai pemberontakan terhadap tatanan sosial budaya akibat gaya hidup liberal, bahkan terkadang anggapan itu muncul di antara kaum perempuan itu sendiri. Pembicaraan mengenai masalah ini tidak pernah mencapai kesepakatan akhir yang memuaskan, bahkan terkadang membuat jemaat semakin bingung karena masing-masing kubu berusaha menggunakan Alkitab sebagai pembenaran pandangan mereka. Kenyataan ini, ditambah dengan perkembangan zaman dan banyak faktor lain yang semakin memberi peluang bagi perempuan untuk berkarya di ranah publik.

Secara normatif, ajaran dan teologi GPIB mengakui kesetaraan pendeta laki-laki dan pendeta perempuan. Secara prinsipil, tidak ada perbedaan antara kedudukan pendeta perempuan dan pendeta laki-laki. Namun kenyataannya, persoalan utama yang sebenarnya belum tersentuh, yakni keberanian memberi kesempatan dan peluang yang lebih luas dalam hal kepemimpinan puncak (ketua majelis sinode) di lingkup sinodal kepada pendeta perempuan. Seharusnya ada tindakan-tindakan konkret untuk menciptakan struktur yang lebih seimbang, yang memberi kesempatan kepada perempuan untuk berpartisipasi lebih luas.
Dalam lingkup sinodal, secara struktur kaum perempuan tidak dipandang utama karena perempuan diakui hanya berperan sebagai sekretaris dan bendahara. Malah itu memperkuat anggapan yang selama ini berlaku bahwa dunia perempuan memang di situ-situ juga baik di rumah maupun di gereja. Kemudian kebijakankebijakan organisatoris yang diskriminatif di struktur lokal (jemaat) perihal penempatan pendeta perempuan, kecenderungan ada penolakan dari sebagian jemaat tertentu untuk penempatan pendeta perempuan. Alasannya, pendeta perempuan kurang tegas, kurang gesit, dan terlalu emosional ketika melayani.

Dari uraian di atas, penulis mengamati usaha kaum perempuan dalam memperjuangkan peran kepemimpinannya, bukan hal yang mudah. Strukur patriarkat yang hierarkis membatasi perempuan untuk berperan. Sementara itu, dari kaum perempuan sendiri secara psikologis mereka kurang berani untuk berperan di tingkat pimpinan tertinggi (ketua umum majelis sinode) karena kuatnya struktur patriarkhi.

\section{Tinjauan Teoritis}

\subsection{Kepemimpinan Umum}

\subsubsection{Pengertian Kepemimpinan}

Secara etimologis, kepemimpinan berasal dari kata pimpin yang berarti bimbing dan tuntun. Kemudian dari kata pimpin muncul kata pemimpin, yakni orang yang berfungsi membimbing atau menuntun. ${ }^{3}$ Kepemimpinan adalah proses mempengaruhi kegiatan-kegiatan

\footnotetext{
${ }^{3}$ Bernadine R. Wiryana, M.S.W \& Susilo Supardo, Kepemimpinan: Dasar-Dasar dan Pengembangannya (Yogyakarta: Andi, 2005), 2.
} 
kelompok yang diorganisir menuju kepada penentuan dan pencapaian tujuan. $^{4}$ Dari pengertian di atas, disimpulkan bahwa kepemimpinan adalah kuasa dan pengaruh.

Sehubungan dengan hal di atas, menurut Yuniyanti Chuzaifah mengutip pandangan Peggy Reeve Sunday bahwa kepemimpinan maskulin lebih cenderung dipahami sebagai kuasa, sedangkan kepemimpinan perempuan seharusnya bukan menguasai, akan tetapi menggerakkan, berbagi kekuatan, pengetahuan dan kesempatan. Artinya, kepemimpinan perempuan tidak maskulin, tidak mendominasi, tidak mendikte dan tidak memaksa orang untuk mengikutinya. ${ }^{5}$

\subsubsection{Peran Pemimpin}

Menurut Siagian, dua jenis gaya yang menentukan peran kepemimpinan yaitu: pertama, kepemimpinan yang mengutamakan tugas yaitu ketika pemimpin merasa puas jika tugas bisa dilaksanakan. Kedua, kepemimpinan yang mengutamakan pada hubungan kemanusiaan. Hal itu, menunjukkan bahwa efektivitas kepemimpinan bergantung pada tingkat adaptasi antara kepemimpinan dan tingkat kondisi yang menyenangkan dalam situasi tertentu. ${ }^{6}$

\footnotetext{
${ }^{4}$ Andreas Lako, Kepemimpinan dan Kinerja Organisasi: Isu, Teori dan Solusi (Yogyakarta: Amara Books, 2004), 10.

${ }^{5}$ Yuniyanti Chuzaifah, Negosiasi Hak Kepemimpinan Perempuan di Ranah Publik: Perspektif Theologi dan HAM Perempuan, dalam Kajian Titik Temu: Kepemimpinan Perempuan dari perspektif Teologi dan HAM Part 2, Jakarta, 06 Juni 2018.

${ }^{6}$ Ibid, Sondang P. Siagian, 112.
}

\subsubsection{Faktor-Faktor yang Mempenga- ruhi Kepemimpinan}

(a) Faktor Kepemimpinan Personal

Pengertian kemampuan personal adalah kombinasi antara potensi pemimpin sejak dilahirkan ke dunia sebagai manusia dan faktor pendidikan yang diperoleh oleh seorang pemimpin. ${ }^{7}$ Jika seorang lahir dengan kemampuan dasar kepemimpinan akan lebih hebat apabila mendapatkan perlakuan edukatif dari lingkungan.

(b) Faktor Jabatan

Pengertian jabatan adalah struktur kekuasaan yang dipimpin oleh seorang pemimpin. ${ }^{8}$ Dalam kehidupan modern saat ini, jabatan merupakan hal yang sangat penting. Banyak orang ingin mendapatkan jabatan bahkan ada yang berambisi menghalalkan segala cara untuk mendapatkan jabatan. Semua organisasi yang terstruktur dengan baik, mengharapkan pemimpin yang memiliki jabatan, yang tidak sewenangwenang dalam menjalankan tugas dan tanggung-jawabnya dan dia selalu memiliki pengaruh yang baik.

(c) Faktor Situasi

Pengertian situasi adalah kondisi yang melingkupi perilaku kepemimpinan. Di saat situasi tidak menentu dan kacau, lebih efektif jika hadir seorang pemimpin yang karismatik. $^{9}$ Jika kebutuhan organisasi sulit untuk maju karena anggota organisasi tidak berkepribadian progresif, maka perlu pemimpin

${ }^{7}$ David Hocking, Rahasia Keberhasilan Seorang Pemimpin, 7 Hukum Kepemimpinan Rohani (Yogyakarta: Yayasan ANDI, 1991), 196.

${ }^{8}$ Ibid, 197.

${ }^{9}$ Sutan G. Pamungkas, Jurus Ampuh Menjadi Pemimpin Dahsyat dan Fenomenal (Yogyakarta: Araska, 2012), 12. 
transformasional. Jika identitas yang dicitrakan organisasi adalah religiositas maka kehadiran pemimpin yang mempunyai kemampuan kepemimpinan spiritual adalah hal yang sangat penting.

\section{Kepemimpinan Kristen}

Kepemimpinan Kristen adalah suatu proses terencana yang dinamis dalam konteks pelayanan Kristen (yang menyangkut faktor waktu, tempat dan situasi khusus) yang di dalamnya ada campur tangan Allah. Dia memanggil bagi diri-Nya seorang pemimpin (dengan kapasitas penuh) untuk memimpin umat-Nya (dalam pengelompokan diri sebagai institusi/organisasi) guna mencapai tujuan Allah (yang membawa keuntungan bagi pemimpin, pengikutnya dan lingkungan hidup) bagi dan melalui umat-Nya, untuk kejayaan kerajaan-Nya. ${ }^{10}$

\section{Tinjauan Teologis Tentang Kepemimpinan Perempuan}

\subsection{Kepemimpinan Perempuan Menurut Perjanjian Lama}

Dalam Perjanjian Lama banyak terdapat contoh perempuan berperan sebagai pemimpin. Peran yang dimaksud adalah peran di keluarga, peran kenabian dan peran yang bersifat sipil. Semua perempuan ini terpanggil untuk memimpin dan melayani sebagai perpanjangan iman Yahudi mereka. Di bawah ini contoh-contoh peran pemimpin perempuan di dalam Perjanjian Lama:

\subsubsection{Pemimpin Perempuan di dalam Keluarga}

Peran pemimpin perempuan di

\footnotetext{
${ }^{10}$ Yakob Tomatala, Kepemimpinan yang Dinamis (Jakarta: Leadership Foundation, 1997), 29.
}

keluarga sangat menentukan kebahagiaan dan keharmonisan di dalam keluarga. Ada pepatah mengatakan bahwa kaum perempuan adalah tiang penyangga dalam suatu bangunan. Maksudnya kehadiran dan peran perempuan adalah sebagai penopang dan kekuatan bagi keluarga. Penulis dalam pembahasan ini membatasi contoh-contoh peran perempuan di dalam keluarga, ada di dalam diri Sarah dan Abigail. Kedua perempuan ini berani memperjuangkan kebahagiaan keluarganya dan sebagai penopang bagi suami dalam menghadapi kesulitan dan tantangan. Sarah dan Abigail adalah perempuan yang kuat dan tangguh bagi keluarganya. Perjuangan dan peran Matriarkh seperti Sarah dan Abigail dalam mewujudkan Israel menjadi bangsa yang besar dan terberkati (mewujudkan janji Allah). Ini menunjukkan bahwa mereka adalah kaum perempuan yang mampu bersikap dan bertindak dan tidak hanya menunggu apa yang terjadi, bahkan menggerakkan kisah sehingga apa yang telah dijanjikan Allah bisa tercapai.

\subsubsection{Pemimpin Perempuan Kenabian}

Tugas seorang nabi adalah penyambung lidah Tuhan. Maksudnya sebagai pemberita Firman. Perempuan sebagai nabiah memang sangat langka dan sulit karena budaya patriarkat yang mendominasi tradisi Perjanjian Lama. Penulis mengangkat tokoh Miryam, Hana, Hulda, dan Debora dalam pembahasan ini, karena keempat perempuan ini adalah nabiah yang berani dalam melayani, memperjuangkan bangsanya dan mereka selalu mengucap syukur kepada Tuhan dalam menjalankan tugas kepemimpinan.

Pertama, Miryam. Dia terlahir 
dalam keluarga Israel pada masa perbudakan di Mesir. Miryam adalah kakak Harun dan Musa. Setelah pembebasan orang-orang Israel melalui Laut Merah, Miryam memimpin bangsa itu dalam perayaan. ${ }^{11}$ Dalam kapasitas ini, Miryam bertindak sebagai pemimpin pujian di depan umum, dengan pengetahuan dan persetujuan penuh dari pemimpin laki-laki yang pada saat itu melayani bersama dengan Miryam. Miryam salah satu pelayan musik yang memiliki karunia nubuat sehingga menjadi pemimpin pujian dan nabiah yang sangat ideal.

Kedua, Hana. Dia adalah seorang perempuan yang hidup takut akan Tuhan dan setia dalam menanti kehendak Tuhan padanya. Doa Hana di rumah Tuhan dan komitmennya kepada Tuhan (1 Sam. 1: 8-2:10) merupakan teladan bagi perempuan-perempuan Kristen saat ini. ${ }^{12}$ Setelah bertahuntahun menderita karena keadaannya yang mandul, Hana menerima kabar bahwa dia hamil. Hana begitu berterima kasih kepada Tuhan atas hadirnya seorang anak sehingga dia bersyukur pada Tuhan melalui pujian.

Ketiga, Hulda. Dia adalah seorang nabiah pada masa pemerintahan Raja Yosia (memerintah Israel sekitar 640-609 SM). Hulda seorang nabiah yang menyampaikan maksud Tuhan, melalui pengarahan kepada bangsanya supaya bangsanya mengalami pembaruan hidup.

Keempat, Debora. Dia seorang nabiah dan pemimpin yang selalu bertindak dengan berani dan tegas dalam menjalankan tugas pengabdiannya. Debora adalah tokoh luar biasa dalam Perjanjian Lama yang

\footnotetext{
${ }^{11}$ St. Darmawijaya, Perempuan dalam Perjanjian Lama (Yogyakarta: Kanisius, 2003), 54.

$$
{ }^{12} \text { Ibid, } 55 .
$$
}

memperlihatkan kompetensi dalam kepemimpinannya. Tercatat dalam Alkitab bahwa Debora adalah seorang nabiah dan istri pada waktu kepemimpinannya (Hak. 4:4).

\subsubsection{Pemimpin Perempuan di Bidang Sipil}

Dalam catatan sejarah suatu bangsa, peran pemimpin perempuan di bidang sipil sangat menentukan kemajuan dalam berbagai bidang, terlebih dalam sistem pertahanan dan keamanan bangsa itu. Ester bertindak sebagai contoh pemimpin perempuan di bidang sipil bagi bangsanya. Ester tergambar jelas sosok perempuan yang kuat dan tangguh dalam memimpin bangsanya. Ester memiliki kemampuan mengarahkan peristiwa-peristiwa umat manusia untuk memberikan keamanan dan keselamatan bagi seluruh bangsa Yahudi yang percaya kepada Tuhan dan yang tinggal di Persia.

\subsection{Kepemimpinan Perempuan Menurut Perjanjian Baru}

Dalam Perjanjian Baru banyak terdapat contoh perempuan yang berperan sebagai pemimpin. Peran yang dimaksud adalah peran kenabian dan peran dalam pelayanan. Di bawah ini contoh-contoh peran pemimpin perempuan pada masa Perjanjian Baru:

\subsubsection{Pemimpin Perempuan Kenabian}

Dalam Perjanjian Baru, ada banyak contoh pemimpin nabiah. Dalam pembahasan ini, penulis mengangkat tokoh Maria, Hana, dan keempat anak perempuan Filipus. Sehubungan dengan itu, penulis melihat dalam diri tokoh-tokoh tersebut jiwa kepemimpinan yang didasari dengan kesungguhan dan ketaatan kepada Tuhan.

Pertama, Maria. Dia adalah 
ibunda Yesus. Dia dipilih Tuhan untuk mengandung Sang Mesias bangsa Yahudi. Ketika Maria tinggal bersama dengan Elisabet, istri imam Zakaria, Elisabet dipenuhi Roh Kudus dan mulai memuji Tuhan atas berkat-Nya dalam diri Mesias yang dikandung oleh Maria. Lalu dia merespon dengan kata-kata pujian yang mengandung nubuat, yang dipenuhi dengan pernyataan-pernyataan nubuat Perjanjian Lama dan yang sudah digenapi dalam diri Yesus Kristus.

Kedua, Hana. Dia sebagai seorang nabiah yang melayani di Bait Suci sepanjang siang dan malam dengan berpuasa dan berdoa (Luk. 2:36-37). Hana bernubuat dengan penuh keberanian di hadapan banyak orang yang berkumpul bersama-sama untuk beribadah di Bait Suci. Hana dipakai untuk meneguhkan bahwa Yesus adalah Mesias, Penyelamat yang dinanti-nantikan oleh bangsa Israel. Hana adalah seorang nabiah yang mempunyai peran penting di dalam kelahiran Yesus dan penyerahan-Nya.

Ketiga, anak perempuan Filipus. Ketika melakukan perjalanan melewati Kaisarea, Paulus dan kawan-kawannya tinggal di rumah Filipus, seorang penginjil yang mempunyai empat orang anak perempuan yang bernubuat (Kis. 21:8-9). Alkitab tidak mengatakan apaapa mengenai pembatasan yang diberikan kepada keempat anak perempuan Filipus tentang pelayanan mereka, sehingga diperkirakan bahwa mereka mempraktikkan karunia nubuat mereka dalam pertemuan-pertemuan umum. Menarik untuk diperhatikan bahwa Nabi Yoel menubuatkan pada masanya, bahwa salah satu ciri khas gereja pada masa yang akan datang adalah perempuan-perempuan akan menggenapi peran nubuat ini (Yl. 2:2832).

\subsubsection{Pemimpin Perempuan di dalam Pelayanan}

Dalam Perjanjian Baru ada banyak pemimpin perempuan dalam pelayanan. Penulis dalam pembahasan ini mengangkat tokoh-tokoh, seperti: Dorkas, Lidia, Febe, Euodia dan Sintike serta Priskila. Tokoh-tokoh ini menginspirasi penulis untuk melihat bahwa di dalam kepemimpinan perempuan tergambar dengan jelas pelayanan mereka mendatangkan kemajuan dan perkembangan gereja dari waktu ke waktu.

Pertama, Dorkas. Di sebuah kota kecil di tepi pantai yang disebut Yope, tinggalah seorang perempuan sederhana bernama Dorkas yang dikenal karena perbuatan-perbuatan baiknya dan kasihnya. Dorkas telah membangun reputasi di masyarakatnya sebagai orang yang akan datang untuk membantu orang-orang tuna wisma, orang-orang miskin dan orang-orang yang membutuhkan.

Kedua, Lidia. Dia sebagai seorang perempuan yang memiliki profesi sebagai pengusaha yang sukses dan seorang anggota gereja khusus di Filipi. Dia masuk menjadi orang Kristen bersama dengan seisi rumahnya. Sebagai seorang non Yahudi dan yang takut akan Tuhan, dia dipandang sebagai pemimpin masyarakat yang telah bertobat, memberikan bantuan dalam pelayanan penginjilan kepada Paulus dan rekanrekannya (Kis. 16:13-15).

Ketiga, Febe. Surat yang ditulis oleh Paulus kepada orang-orang percaya di Roma diakhiri dengan serangkaian salam kepada temantemannya. Di dalam tulisan Paulus, dia memperkenalkan kepada gereja-gereja di Roma bahwa ada seorang diaken perempuan (diakonon) yang bertempat tinggal di kota pelabuhan timur 
Kengkrea yang bernama Febe.

Keempat, Euodia dan Sintike.

Ketika Paulus menulis kepada gereja di Filipi, dia menghargai sumbangsih yang diberikan oleh kedua perempuan di gereja itu dalam pelayanannya (Flp. 4:3). Paulus berbicara tentang Euodia dan Sintike sebagai dua perempuan yang bekerja bersama-sama dengan dia dalam pekabaran Injil. Paulus bersama kedua perempuan ini jelas melakukan tanggung jawab yang penting hanya untuk Yesus Kristus.

Kelima, Priskila. Priskila dan Akwila (suaminya) menjelaskan kepada Apolos jalan Tuhan secara lebih akurat (Kis. 18:26-28). Penting untuk menjadi perhatian bahwa hampir semua referensi kepada tim pelayanan suamiistri ini, nama Priskila disebutkan terlebih dahulu. Sebagian orang memahami hal ini adalah suatu tanda bahwa peran kepemimpinan yang dimiliki Priskila dalam aspek pengajaran dari pelayanan bersama mereka. Menurut Paulus istilah "pasangan ini”, merujuk pada Priskila dan Akwila yang bersedia mempertaruhkan nyawanya demi gereja non-Yahudi (Rm. 16:4).

Dengan demikian, bertolak dari visi Alkitab (Perjanjian Lama dan Perjanjian Baru), penulis menyimpulkan beberapa hal sebagai berikut:

a. Allah menghendaki kepemimpinan perempuan pada lingkup sosial mana pun, terutama pada lingkup gereja, karena Allah menciptakan perempuan setara dan sejajar dengan laki-laki dan memanggilnya untuk ikut berkuasa atas seluruh ciptaan Allah (Kej. 1).

b. Kepemimpinan perempuan tidak menjadikan perempuan lebih tinggi kedudukannya dari laki-laki dan karena itu menjadi dominan atas laki-laki. Sebaliknya, sebagai pemimpin perempuan harus menerapkan kepemimpinan sebagai mitra yang sejajar dengan laki-laki (Kej. 2).

c. Gaya kepemimpinan perempuan harus lebih terarah sebagai upaya membangun dan membela kehidupan. Oleh karena itu, seorang perempuan pemimpin harus berusaha menggunakan kuasa yang dia peroleh dalam kepemimpinannya untuk membangun kehidupan bersama yang sejahtera dan adil.

\section{Tinjauan Pedagogis tentang Kepemimpinan Perempuan}

\subsection{Pedagogis bagi Perempuan}

Istilah pedagogi berasal dari bahasa Yunani. Pedagogis terdiri dari kata "paedos" yang artinya anak lakilaki dan kata "agogos" yang artinya mengantar membimbing. Jadi pengertian dasar pedagogis adalah seorang ahli yang membimbing anak ke arah tujuan hidup tertentu, agar kelak dia mampu secara mandiri menyelesaikan tugas hidupnya. ${ }^{13}$ Dari pengertian dasar pedagogis ini disimpulkan bahwa pedagogis menuju masa depan adalah pedagogis yang membuka pintu bagi pemimpin perempuan agar bisa mewujudkan citacita sesuai minat dan bakatnya masingmasing. Mereka menjadi pribadi yang mandiri dan siap berkolaborasi. ${ }^{14}$

Sejalan dengan itu, menurut Djoys Anneke Rantung bahwa pendidikan adalah suatu tindakan untuk membimbing keluar dari kebodohan,

\footnotetext{
${ }^{13}$ Edward Sallis, Total Quality

Management in Education, Manajemen Mutu Pendidikan (Yogyakarta: IRCiSoD, 2012), 169.

${ }^{14}$ Haryono, Jurnal Teologi dan Misi: Pendidikan berkualitas di Geneva, 2012, 45.
} 
kemalasan, kekerasan, keterbelakangan, kemiskinan, ketidaktahuan atau ketidakmengertian supaya tidak bodoh, tidak malas, tidak hidup dalam kekerasan, tidak miskin, tidak terbelakang, supaya dari tidak tahu menjadi tahu atau dari tidak mengerti menjadi mengerti atau paham akan sesuatu terutama hal-hal berguna atau bermanfaat. ${ }^{15}$

Jadi, pendidikan bagi perempuan adalah proses pengubahan sikap dan tata laku seseorang atau kelompok orang dalam usaha mendewasakan perempuan melalui upaya pengajaran dan pelatihan. Pada dasarnya pendidikan selalu menuju proses pembentukan kepribadian secara menyeluruh yang terjadi terus-menerus atau secara berkesinambungan. pendidikan terhadap perempuan harus berorientasi pada kurikulum yang sensitif-gender sehingga berdampak pada kesetaraan yang berkeadilan. Aspek penting dari pedagogis kepemimpinan perempuan adalah memberdayakan kaum perempuan dan memberi mereka wewenang yang luas untuk meningkatkan pembelajaran. Kaum perempuan diberi wewenang untuk mengambil keputusan, sehingga mereka memiliki tanggung jawab yang besar. Mereka diberi keleluasan dan otonomi untuk bertindak.

\subsection{Metode Andragogi}

Salah satu langkah untuk melakukan pemberdayaan perempuan adalah melakukan proses pembelajaran kepada perempuan. Metode yang tepat dalam pembelajaran perempuan salah satunya dengan pendekatan andragogi.

\footnotetext{
${ }^{15}$ Djoys Anneke Rantung, Resolusi Konflik dalam Organisasi; Kajian dari Perspektif Pendidikan Perdamaian terhadap Kasus Konflik di Lembaga Pendidikan (Jakarta: BPK Gunung Mulia, 2017), 42.
}

Andragogi perempuan adalah suatu metode yang dilakukan dalam proses pembelajaran bagi perempuan secara menyeluruh dan berkelanjutan. ${ }^{16}$ Dalam pendekatan andragogi pada pembelajaran pemimpin perempuan adalah:

a. Perempuan dipandang sebagai perempuan yang memiliki citra diri perempuan dewasa yang matang dan mandiri. Menjadi penting memahami pendidikan citra diri perempuan sebagai perempuan yang telah matang dan mandiri. Pembelajaran bagi perempuan harus didasari dengan hubungan yang bersifat timbal-balik dan saling membantu.

b. Perempuan dipandang sebagai orang yang memiliki pengalaman. Pemimpin perempuan dalam realita kehidupan adalah orang yang memiliki pengalaman beragam. Pengalaman yang beragam dianggap sebagai sumber kekayaan dalam proses pembelajaran sehingga proses pembelajaran dengan cara-cara yang bersifat diskusi kelompok, simulasi, permainan peran dan lain-lain. Dalam proses pembelajaran seorang pemimpin perempuan dan semua pengalaman peserta belajar didayagunakan sebagai sumber dan inspirasi belajar.

c. Belajar bagi pemimpin perempuan dipandang sebagai proses pemecahan masalah. Belajar bagi perempuan adalah upaya pemecahan masalah perempuan itu sendiri, seperti ketimpangan gender dalam berbagai segi kehidupan, mulai dari problem pendidikan, kesehatan, politik dan lainnya.

\footnotetext{
${ }^{16}$ Siti Fatimah \& Wirdanegsih, Gender dan Pendidikan Multikultural (Jakarta: Kencana, 2016) 135.
} 


$\begin{array}{llr}\text { Pembelajaran } & \text { bagi } & \text { pemimpin } \\ \text { perempuan } & \text { dengan } & \text { metode } \\ \text { andragogi } & \text { adalah } & \text { mampu } \\ \text { memecahkan masalah hari ini. }{ }^{17}\end{array}$

Jadi, pembelajaran yang dilakukan kepada perempuan bertujuan meningkatkan kualitas diri dari perempuan dengan belajar secara kontekstual dengan pengalaman kehidupan perempuan itu sendiri. Artinya perempuan belajar menemukan serta menghargai, mengembangkan proses belajar yang khas perempuan sehingga pengalaman perempuan membuka jalan baru bagi kontribusi pembelajaran perempuan yang khas perempuan.

\subsection{Pedagogis sebagai Sarana Emansipasi Perempuan}

Kartini adalah tokoh perempuan Indonesia pertama yang menggagas dan mencetuskan istilah emansipasi. Kartini menyadari budaya negerinya tegastegas membedakan laki-laki dan perempuan secara hirarkis. Posisi lakilaki pada pimpinan utama, sementara perempuan berada pada posisi bawahan. $^{18}$ Diskriminasi tersebut dirasakan Kartini sangat merugikan kaumnya. Dia melihat peristiwaperistiwa yang terjadi di luar rumah (public sphere) begitu bergerak, dinamis, serta progresif. Karena lakilaki lebih banyak melakukan aktivitas di situ dengan sendirinya hal-hal yang berkaitan dengan kemajuan sangat menguntungkan laki-laki. Kejadian yang berlangsung dalam rumah (domestic sphere) rutin dan monoton, tidak banyak tersentuh perubahan.

Pendidikan bagi Kartini adalah

${ }^{17}$ Ibid, 136.

${ }^{18}$ Surat-surat Kartini kepada Nyonya Abendanon, Jepara, Agustus 1900, lihat kartini, Surat-surat kepada R.M. Abendanon-Mandri dan suaminya (Jakarta: Djambatan, 1987), 14. pembuka jalan yang memungkinkan perempuan dapat berkiprah di dunia luas dan mampu mengikuti perubahan yang terus menerus berlangsung sertra memiliki posisi serta peran intelektual dan sosial. Pendidikan juga dapat menetralisir perbedaan sifat kelakilakian dan keperempuanan yang merupakan hasil rekayasa budaya tersebut. Kartini meyakini bahwa pendidikan sekolah dapat menghilangkan perbedaan prasangka itu, yang tinggal hanyalah kodrati biologisnya, seperti yang ditulis dalam suratnya: "bahwa kita dapat menjadi manusia sepenuhnya, tanpa berhenti menjadi wanita sepenuhnya" 19

\section{Kepemimpinan Pendeta Perempuan menurut Konteks GPIB}

\subsection{Kepemimpinan di GPIB}

Kepemimpinan di GPIB menganut paham presbiterial sinodal. Paham presbiterial sinodal dijelaskan dalam penjelasan tentang pokok gereja dan pemahaman iman GPIB yang menyatakan bahwa GPIB mengatur pelayanannya secara presbiterial sinodal, yakni suatu sistem kepemimpinan yang dilakukan oleh para pejabatnya (pendeta, penatua, diaken dan pengnjil), keputusannya selalu diambil secara bersama (sinodal). ${ }^{20}$ Sistem ini sesungguhnya berasal dari tradisi Calvinis yang sangat mewarnai kehidupan GPIB. Sistem ini juga menghidupkan hubungan timbal balik antara jemaat (majelis jemaat)

${ }^{19}$ Ibid, Surat-surat Kartini kepada Nyonya Abendanon, Jepara, Agustus 1900, lihat kartini..., 22.

${ }^{20}$ C. Wairata, "Kepemimpinan: Suatu Tinjauan Kepejabatan dari Perspektif Ekklesiologi menurut paham GPIB", dalam Ministrium Buletin Teologi Gereja (Volume 2, Nomor 2, Januari-Juni 2003), 36. 
dengan pimpinan gereja (majelis sinode), maksudnya hubungan yang dinamis, kaitan yang hidup dan kepentingan timbal-balik untuk melaksanakan misi Kristus. ${ }^{21}$ J.I.C.H. Abineno dalam bukunya Garis-garis Besar Hukum Gereja mengatakan bahwa pikiran dasar dan sistem atau susunan presbiterial sinodal ialah bahwa pimpinan gereja oleh Kristus sebagai Kepala dan tubuh-Nya adalah jemaat. Pimpinan dan pemerintahan ini berlangsung berkat pekerjaan Firman dan Roh-Nya. Pemerintahan gereja, baik sebagai persekutuan maupun sebagai institusi atau lembaga dijalankan-Nya dengan perantaraan pejabat-pejabat gerejawi sebagai alat atau hamba-hamba-Nya. ${ }^{22}$

Salah satu hal pokok yang digumuli oleh GPIB dalam menjalankan kepemimpinannya adalah meningkatkan sumber daya insani dengan cara mengembangkan diri sesuai dengan karunia dan talenta, serta proaktif dan kreatif dalam menghadapi tantangan dan tuntunan kebutuhan Gereja dan masyarakat. Kualitas sumber daya insani tampak dalam kualitas pribadi warga Gereja untuk dapat mengembangkan hubungan dengan sesama manusia, sebab manusia hidup saling bergantung satu dengan yang lain. Menurut C. Wairata bahwa manusia hidup dalam tiga dimensi, yakni dalam relasi dengan Allah, dengan sesamanya dan dengan ciptaan Tuhan lainnya. ${ }^{23}$ Artinya hubungan dengan Allah harus menunjukkan kualitas spiritual yang tercermin dalam

\footnotetext{
${ }^{21}$ Majelis Sinode GPIB, Kurikulum

Katekisasi GPIB (Jakarta: Majelis Sinode GPIB, 2010), 111.

${ }^{22}$ J. I. C. H, Abineno, Garis-Garis Besar Hukum Gereja: dalam Wairata, Kepemimpinan menurut paham GPIB (Jakarta, 2003), 51.

${ }^{23}$ Ibid, C. Wairata
}

ketaatan dan kesetiaan kepada Allah yang diekspresikan dalam kaitannya dengan solidaritas sosial yang bertanggung jawab terhadap sesama dan bersikap adil, benar dalam mengelola dan memelihara alam dan sumber daya alam untuk kesejahteraan seluruh ciptaan. Dengan demikian GPIB wajib berupaya mengembangkan sumber daya yang dia miliki serta mengembangkan karunia dan talenta yang dimiliki dalam mengemban tugas panggilan dan pengutusannya.

Sehubungan dengan hal itu dalam mengemban tugas panggilan dan pengutusannya harus memiliki kejelasan arah hidup (baca kepemimpinan dan pelayanan) berdasarkan visi dan misi GPIB. Yang dimaksud dengan visi adalah kehendak Kepala Gereja dan pemilik Gereja yang harus dipenuhi sampai kedatangan-Nya kembali. Jadi, masalah-masalah yang mempunyai jangkauan jangka panjang dan dampaknya perlu mendapat perhatian yang serius dengan membuat prakiraan yang obyektif atas keadaan maupun kecenderungan yang terjadi dalam lingkungan sekitar GPIB. ${ }^{24}$ Visi, Misi GPIB sejalan dengan motto/semboyan GPIB yang menegaskan bahwa dalam menunaikan tugas panggilan dan pengutusannya, kepemimpinan di GPIB harus mengalami damai sejahtera Yesus Kristus dan harus dicapai dengan citra diri sebagai pembawa damai sejahtera Yesus Kristus. Karena itu, dalam kehadirannya, dia harus selalu melakukan tindakan damai sejahtera dengan menjadikan dirinya sebagai berkat di tengah masyarakat, bangsa dan negara bahkan dunia.

$$
{ }^{24} \text { Ibid, } 98 .
$$




\subsection{Pengertian Pendeta di GPIB}

Dalam Alkitab istilah pendeta adalah pelayan, gembala atau gembala sidang yang memiliki makna pemimpin jemaat dan menjadi penatalayanan yang harus melayani jemaat (leadership is ministry). ${ }^{25}$ Menurut ketetapan persidangan sinode XX di Balikpapan (KALTIM) menjelaskan istilah pendeta GPIB adalah:

Pegawai GPIB yang diteguhkan sebagai pelayan firman dan sakramen yang ditugaskan oleh majelis sinode pada jabatan struktural di GPIB. Pendeta jemaat adalah jabatan fungsional yang diberikan kepada seorang pendeta yang diangkat dan ditugaskan oleh majelis sinode. Di GPIB juga dikenal istilah pendeta pelayanan umum dan pendeta non organik. Pendeta pelayanan umum adalah pegawai GPIB yang diteguhkan sebagai pelayan firman dan sakramen dan pejabat struktural namun tidak/belum ditugaskan di jemaat. Pendeta non organik adalah pendeta GPIB namun bukan pejabat struktural, karenanya tidak berstatus pegawai. ${ }^{26}$

\subsection{Tugas dan Tanggung Jawab Pendeta di GPIB}

Tugas dan tanggung jawab umum pendeta adalah menjaga kemurnian ajaran gereja, ketertiban dan keteraturan peribadahan, pelayanan sakramen, penggembalaan, pembinaan warga gereja serta pelayanan kasih dan keadilan. $^{27}$ Tugas khusus pendeta

${ }^{25}$ A. Maitimoe, Kepemimpinan yang Melayani, dalam Ministrium Buletin Teologi Gereja, vol. 2, nomor 2 (Jakarta, Januari-Juni 2003), 81.

${ }^{26}$ Majelis Sinode, Ketetapan Persidangan Sinode XX GPIB (Jakarta, 2015), 182.

${ }^{27}$ Tata Gereja GPIB, peraturan nomor 1 , pasal 2a, buku IV (Jakarta: Majelis Sinode GPIB), 65 . adalah melaksanakan pemberitaan firman dan pelayanan sakramen, menjaga kemurnian ajaran dan penggembalaan khusus, peneguhan presbiter, pengurus dan pelayanan kategorial (PELKAT) dan perkenalan pelaksana harian majelis jemaat (PHMJ) serta pengurus unit misioner. ${ }^{28}$

\subsection{Perupaan Pendeta GPIB}

Perupaan pendeta adalah proses melengkapi seorang sarjana teologi untuk menjadi pendeta, pelayan firman dan sakramen GPIB. ${ }^{29}$

\subsection{Pendeta Perempuan dalam Jabatan Struktural di GPIB}

Sejak keputusan persidangan sinode GPIB tahun 1978 di Kuningan, Jakarta, dinyatakan bahwa pendeta perempuan yang menikah, baik dengan sesama pendeta maupun dengan nonpendeta dapat melayani dalam bidangbidang pelayanan umum dan kategorial sebagai pendeta. ${ }^{30}$ Pada persidangan sinode XIII 1982, jabatan ketua majelis jemaat tidak dipermasalahkan apakah harus laki-laki ataupun perempuan. Dengan kata lain, perempuan pendeta baik yang belum menikah maupun yang sudah berumah-tangga dapat menjabat sebagai ketua majelis jemaat. ${ }^{31}$

Delapan tahun setelah persidangan Sinode XII, dalam persidangan sinode XIV 1986 di Bali, ditegaskan kembali ketentuan tentang pendeta perempuan dalam sebuah akta gereja. ${ }^{32}$ Akta adalah petunjuk praktis

\footnotetext{
${ }^{28}$ Ibid, 66.

${ }^{29}$ Ibid, 74-75.

${ }^{30}$ S. W. Lontoh \& Hallie Jonathans,
} Bantera Guna Dharma GPIB (Jakarta: BPK Gunung Mulia, 2014), 221.

${ }^{31}$ Majelis Sinode GPIB, Ketetapan Persidangan Sinode XIV (Jakarta, 1986), 69.

${ }^{32}$ Majelis Sinode GPIB, Ketetapan Persidangan Sinode XIX (Jakarta, 2010), 129. 
mengenai masalah yang belum ditetapkan dalam peraturan gereja, akta merupakan hasil telaah situasi beserta pembahasan teologis yang memberikan dasar dan pedoman penyelesaian. ${ }^{33}$ Pada persidangan Sinode ke XV 1990 diputuskan kata wanita (perempuan) dalam akta yang menyangkut pendeta wanita (perempuan) dihapuskan. ${ }^{34}$ Berdasarkan hal itu, tidak lagi diperlukan akta gereja tentang pendeta perempuan. Jadi, di GPIB hanya berlaku satu istilah saja, yaitu pendeta tanpa membedakan pendeta perempuan atau pendeta laki-laki. ${ }^{35}$

Dengan demikian, dapat disimpulkan bahwa sejak keputusan persidangan sinode tahun 1976 di Kuningan Jakarta, sampai saat ini pendeta perempuan diperlakukan sama dengan pendeta laki-laki. Jabatan ketua majelis jemaat dapat diduduki oleh lakilaki ataupun perempuan. ${ }^{36}$ Dengan kata lain, pendeta perempuan, baik yang belum menikah maupun yang sudah menikah dapat menjadi seorang pemimpin dengan jabatan ketua majelis jemaat maupun pendeta jemaat. ${ }^{37}$

\subsection{Masalah-Masalah Kepemimpinan Pendeta Perempuan di GPIB}

Berdasarkan jejak rekam historis didapati bahwa pembedaan itu sering kali bersumber pada permasalahan

\footnotetext{
${ }^{33}$ Majelis Sinode GPIB, Ketetapan

Persidangan Sinode XX GPIB, Buku I,

Pemahaman Iman dan Akta Gereja (Jakarta, 2015), 210.

${ }^{34}$ Majelis Sinode GPIB, Ketetapan

Persidangan Sinode XV (Jakarta, 1990) 85.

${ }^{35}$ Ibid, Maria Josephine Mantik,

Mengapa Perempuan dipersulit Menjadi

Pemimpin, Saat Perempuan Menjawab

Panggilan dan Pengutusan Tuhan (Jakarta: PT

Grasindo, 2012), 55.

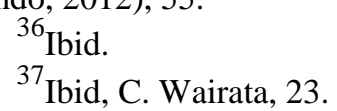

hirarki patriarki dan gender. Karena itu, permasalahan-permasalahan perempuan yang berdampak pada kepemimpinan pendeta perempuan di lingkup sinodal GPIB berikut ini:

\subsubsection{Masalah Patriarki}

Menurut Josef M.N. Hehanussa, masalah patriarki dalam kepemimpinan di GPIB seperti penyelesaian konflik yang melibatkan pendeta sering kecenderungan menggunakan pola pendekatan kekuasaan. Dia memiliki kesan bahwa kepemimpinan di GPIB menganut sistem papal yang hierarkis. Hal ini terlihat dari begitu besarnya kuasa yang dimiliki majelis sinode dalam mengatur seluruh sistem dan tatanan yang ada di GPIB. ${ }^{38}$ Untuk menghapus hirarki jabatan yang sudah lama dirasakan menghambat pelayanan, maka dirumuskan kembali tugas-tugas masing-masing jabatan yang ada dan ditegaskan bahwa semua jabatan itu bukan untuk diri sendiri tetapi untuk melayani. ${ }^{39}$

Selain hal di atas, menurut Paul Waney bahwa masalah patriarki di GPIB membentuk kecenderungan pola parokial bagi pendeta perempuan sebagaimana yang dikatakannya di bawah ini.

"Pendeta perempuan lebih ingin ditempatkan di tengah-tengah jemaat daripada berada dalam suatu intansi. Hal ini disebabkan karena jemaat memiliki variasi hidup yang lebih luas, ditambah faktor waktu kerja lebih

\footnotetext{
${ }^{38}$ Josef M.N. Hehanussa, Masih Ada banyak Pekerjaan Rumah untuk Kita, dalam Suarakanlah Kebenaran, Menyikapi Persoalan dalam Tubuh GPIB (Jakarta: Komunitas Peduli Reformasi GPIB, 2015), 138.

${ }^{39}$ Hendrik Ongirwalu, Sejarah Gereja Protestan di Indonesia, jilid 1 (Jakarta: Badan Pekerja Harian Gereja Protestan di Indonesia, 2005), 222.
} 
fleksibel dibanding bila bekerja dalam suatu instansi yang memiliki waktu yang ketat. Tampaknya kecenderungan kepemimpinan pendeta perempuan berperan pada tugas-tugas yang parokial. Ini disebabkan karena jalur bidang fungsional atau bidang kategorial masih amat sedikit terbuka. Faktor lainnya, disebabkan berada di jemaat adalah suatu peranan yang dianggap dia menjadi pendeta. $" 40$

Pemahaman di atas memberikan suatu pengertian bahwa pola parokial adalah pola kepemimpinan di jemaat yang bertumpu pada perorangan, yakni tertuju pada para pejabat gereja. Pola parokial ini cenderung memposisikan warga jemaat sebagai obyek (sasaran) dari pelayanan jemaat. Secara sistematis, jemaat tidak diikutsertakan dalam pelayanan gereja. Kepasifan peran warga jemaat ini semakin menutup kemungkinan gereja dapat membangun hubungan dengan golongan fungsional maupun kategorial di dalam masyarakat saat ini. ${ }^{41}$

Masalah lain yang ditimbulkan dari sistem patriarkat yang hierarkis adalah masalah kolegialitas. Menurut kamus besar bahasa Indonesia kolegialitas adalah rasa setia kawan terhadap teman sejawat. $^{42}$ Masalah yang real adalah kolegialitas mempengaruhi pendeta yang aktif dan pendeta yang pensiun. Intinya masalah kesejahteraan pada diri pendeta yang

\section{${ }^{40}$ Paul Waney, Peranan Wanita}

Berpendidikan Teologi di Perkotaan, dalam Berikanlah Aku Air Hidup itu: Bahan Sumbersumber Studi Gender, hasil Konsultasi dan Lokakarya Wanita Berpendidikan Teologi Persetia dan Biro Pelayanan (Jakarta: PERSETIA, 1997), 68.

${ }^{41}$ D. R. Maitimoe, Membina Jemaat Misoner (Jakarta: BPK Gunung Mulia, 1984), 32.

${ }^{42}$ https://kbbi.kemdikbud.go.id, diakses tanggal 26 April 2018. mempengaruhi kolegialitas pendeta dengan sesama pendeta. ${ }^{43}$ Masalah kolegialitas pada akhirnya berdampak terhadap kepemimpinan pendeta perempuan di GPIB.

\subsubsection{Masalah Gender}

Masalah-masalah gender berdampak pada kepemimpinan pendeta perempuan di GPIB, yaitu:

(a) Marginalisasi

Marginalisasi adalah usaha membatasi peran terhadap kelompok tertentu menempatkan atau menggeserkan ke pinggir. Marginalisasi perempuan adalah suatu proses pemiskinan atas satu jenis kelamin tertentu dalam hal ini perempuan. ${ }^{44}$ Menurut C. Wairata, seorang pendeta senior di GPIB, membangun pemahaman kepemimpinan perempuan di GPIB pada masa awal dirasakan tidaklah mudah. Dalam kondisi ketiadaan sumber daya perempuan yang berpendidikan tinggi, perempuan cenderung kurang diperhitungkan dalam organisasi masyarakat dan gereja yang anggotanya campuran laki-laki dan perempuan. ${ }^{45}$ Di dalam GPIB, ada ketentuan bagi pendeta perempuan untuk berhenti dari jabatan pendeta apabila menikah dalam jenjang waktu dua tahun setelah hari pentahbisannya. $^{46}$ Peraturan ini dianggap diskriminatif dibandingkan dengan perlakuan terhadap pendeta laki-laki yang tidak mengalami pembatasan yang sama. Selain hal di atas, adanya peraturan bahwa pendeta perempuan sesudah menikah, karier

\section{${ }^{43}$ Aart Van Beek, Pendampingan}

Pastoral (Jakarta: BPK Gunung Mulia, 2001),

21.

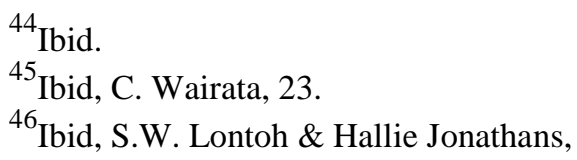
199. 
pelayanannya terhenti karena dia harus mengikuti suaminya. Situasi ini dapat mengakibatkan karier pendeta perempuan itu sendiri tidak akan berkembang dan mengalami kemunduran.

Menurut Margie I. Ririhena-de Wanna, realita di atas memberi kesan bahwa pelayanan di gereja hanya milik kaum laki-laki yang berkutat dalam porsi pengambilan keputusan yang menentukan arah bergereja. Hal ini ada keterkaitannya dengan kebiasaan di dalam pelayanan, pada umumnya menggambarkan laki-laki sebagai tokoh pelaku pelayanan dan lembaga dengan semua aktivitas yang dikendalikan oleh laki-laki. Seringkali dalam posisi ini, perempuan hanya dianggap sebagai pengikut atau sekadar tokoh pembantu, seakan tidak memberikan kontribusi apa pun terhadap pelayanan tersebut, walaupun dalam kenyataannya perempuan-perempuan telah menjadi pelaku utama dalam pelayanan. Hal ini dipengaruhi oleh budaya patriarkat yang memarginalisasi perempuan. ${ }^{47}$

\section{(b) Subordinasi dalam Gereja}

yang $\begin{array}{cr}\text { Masalah-masalah } & \text { subordinasi } \\ \text { dapat } & \text { mempengaruhi }\end{array}$
kepemimpinan pendeta perempuan di GPIB:

- Pola gender subordinasi antara pendeta-pendeta sebagai fungsionaris majelis sinode dengan pendeta-pendeta di jemaat atau lembaga. Situasi ini memperlihatkan pola komunikasi yang terkesan superior dan inferior. Situasi ini lebih memprioritaskan kuasa pihak yang satu atas pihak yang lain.

- Pola gender subordinasi antara

${ }^{47}$ Margie I. Ririhena-de Wanna, Merajut Identitas Eklesiologi di Seputar Konflik Lombok (Jakarta: BPK Gunung Mulia, 2016), 183. ketua majelis jemaat dan pendeta jemaat artinya penulis mengamati umumnya ketua majelis jemaat melihat pendeta jemaat sebagai saingan, begitu juga sebaliknya.

- Almamater dan suku, kedua hal ini sering membangun primordialisme dalam diri pendeta GPIB. Primordialisme ini terlihat ketika penempatan para pendeta dan pemilihan majelis sinode.

- Pola gender subordinasi terhadap pendeta organik, pendeta pelayanan umum dan pendeta non organik. Realitanya pendeta organik dilihat sebagai pendeta kelas satu sedangkan pendeta pelayanan umum dan pendeta non organik sebagai pendeta kelas dua. ${ }^{48}$

Selain itu, pola subordinasi terhadap perempuan yang hanya menduduki posisi jabatan berdasarkan kepantasannya, misalnya sebagai sekretaris atau bendahara. Sementara, jabatan ketua atau pengambil keputusan masih didominasi oleh laki-laki. ${ }^{49}$

\section{(c) Stereotipe dalam Gereja}

Stereotipe adalah adanya pelabelan atau penandaan terhadap satu kelompok tertentu yang merugikan dan menimbulkan ketidakadilan. Stereotipe di dalam kepemimpinan pendeta menunjukkan pelabelan di antara dua jenis kelamin, yaitu perempuan dan laki-laki. Perempuan mempunyai posisi yang rendah daripada laki-laki. Pelabelan ini secara sosial budaya lakilaki dikontruksi sebagai orang yang kuat sementara perempuan terlanjur dengan pelabelan yang lemah lembut. ${ }^{50}$

Stereotipe dalam masyarakat dan

$$
{ }^{48} \text { Ibid, Joseph M.N. Hehanussa, 136- }
$$

137.

\footnotetext{
${ }^{49}$ Ibid, Maria Josephine Mantik, 90.

${ }^{50}$ Ibid, Maria Josephine Mantik, 98.
} 
budaya telah membentuk laki-laki dan perempuan dalam perannya di tengahtengah masyarakat dan gereja. Sehubungan dengan hal itu, dalam pelayanan di GPIB tidak jauh berbeda, seringkali pendeta perempuan ditempatkan di daerah yang mudah dan terjangkau dengan transportasi yang memadai. Karena perempuan rentan dengan masalah-masalah kekerasan dan pelecehan. Secara psikologis, berdampak dalam jiwa perempuan itu sendiri, yang pada akhirnya perempuan itu sendiri tidak bersedia memimpin dalam perhelatan yang besar. Pada akhirnya terjadi dikotomi domestik dan publik. Sejalan dengan itu, menurut Gerrit Singgih bahwa pendeta perempuan menjadi pendeta jemaat GPIB dan menikah, tetapi dia menanggung sangat banyak persoalan yang tidak ditanggung oleh pendeta jemaat laki-laki. Hal ini mengakibatkan keseluruhan kedudukan perempuan dalam struktur kepemimpinan gereja atau jemaat masih sangat lemah. ${ }^{51}$

Dari uraian di atas, peneliti menyimpulkan bahwa masalah (hambatan) kepemimpinan pendeta perempuan yang sangat mendasar adalah budaya patriarki dan bias gender. Selain itu, pola gender subordinasi yang masih membudaya dan kental dalam tugas-tugas pelayanan pendeta di GPIB berdampak terhadap kepemimpinan pendeta perempuan di lingkup sinodal.

\footnotetext{
${ }^{51}$ E.G. Singgih, Implikasi Gender dalam Lembaga Pendidikan Teologi, dalam Berikanlah Aku Air Hidup itu, bahan sumbersumber studi Gender, hasil Konsultasi dan Lokakarya Wanita Berpendidikan Teologi Persetia dan Biro Pelayanan (Jakarta: PERSETIA, 1997), 27.
}

\subsubsection{Kilas Balik Kepemimpinan Pendeta Perempuan di GPIB}

Masuknya sejarah modernisasi, emansipasi perempuan dan pengaruh budaya barat ke-Indonesia menyebabkan adanya pergeseran kedudukan dan relasi gender, termasuk dalam gereja. Tuntutan adanya kesetaraan antara laki-laki dan perempuan merupakan penyebab utama dalam pergeseran kedudukan dan relasi gender tersebut. Salah satu lembaga yang merespon positif pada konsep kesetaraan tersebut adalah Gereja Protestan di Indonesia bagian Barat (GPIB). Gereja ini memberikan dukungan penuh terhadap perempuan untuk menduduki posisi atau peran strategis dalam lembaganya sebagai seorang pendeta untuk memimpin jemaatnya.

Peran strategis dengan menjadi pendeta yang telah dicapai oleh pendeta perempuan dalam Gereja Protestan di Indonesia bagian Barat, tentunya tidak didapatkan dengan cara yang mudah, terdapat serangkaian proses yang cukup berat dalam merubah stigma masyarakat mengenai citra dan peran perempuan yang telah dikonstruksikan sebelumnya. Mengingat GPIB merupakan gereja yang heterogen dan warga jemaatnya terdiri dari berbagai latar belakang suku dan budaya sehingga cenderung mempengaruhi perspektif pendeta perempuan sebagai pemimpin, tentunya proses yang dijalani akan berbeda dengan proses yang dijalani oleh pendeta perempuan pada umumnya. Dalam konteks menggereja seperti inilah, pendeta perempuan GPIB membangun dirinya dan kepemimpinannya dengan memahami historisitas dalam rangka kesadaran sejarah, yakni memdorong dirinya memberi fokus pada keberadaannya kini. Historisasi 
kepemimpinan pendeta perempuan GPIB sebagai berikut:

\section{(a) Gerak Perempuan Pra-GPIB}

Menurut Hendrik Ongirwalu dan Cornelis Wairata, sejak awal persekutuan kaum ibu di jemaat-jemaat lokal Gereja Protestan Indonesia (GPI) sebelum nantinya menjadi GPIB yang mandiri, persekutuan kaum perempuan memiliki ciri pelayanan yang memiliki model pengorganisasian, model kegiatan yang berbeda satu dengan yang lainnya. Artinya kegiatan kaum ibu lebih menyesuaikan dengan kebutuhan dan konteks jemaat lokal. Kegiatan ibu-ibu bersama dengan kaum pemuda dan anak menunjukkan kegiatan dalam hal berdoa dan kesalehan. Pada masa itu kaum ibu dikenal dengan kelompok-kelompok doa dan kesalehan dengan motivator dari para penginjil, guru dan pendeta dari Minahasa, Maluku dan Timor yang kehadirannya di luar wilayah pelayanan masing-masing sinode mereka, dikoordinasi oleh Gereja Protestan Indonesia (GPI) dalam rangka memelihara iman jemaat-jemaat GPI di Jawa, Sumatra, Kalimantan dan Sulawesi Selatan. Kelompok kesalehan dan doa ini telah menginspirasi jemaat untuk bertumbuh dan sekaligus memberdayakan warga jemaat untuk menjadi berkat melalui kehadiran dan partisipasinya dalam konteks bergereja saat itu. ${ }^{52}$ Kaum ibu pada era ini, lebih banyak bergerak dalam bidang kerohanian dengan melaksanakan ibadah-ibadah, pelayanan doa, diakonia dan penginjilan. Gerak kaum ibu (persekutuan kaum perempuan) lebih pada kegiatan-kegiatan sosial sebagai respons atas pembacaan dan

\footnotetext{
${ }^{52}$ Ibid, Hendrik Ongirwalu dan Cornelis Wairata, 58-59.
}

pemberitaan Firman Tuhan sehingga berdampak postif bagi pelayanan sosial kemasyarakatan.

\section{(b) Pendeta Perempuan GPIB di Awal Kemandirian}

Sebelum era ini, Indische Kerk, tepatnya pada tahun 1947 dan 1948, Gereja Protestan Indonesia (GPI) mengutus pertama kalinya dua warga putrinya, yaitu Chatarina Louise Manusama (masuk tahun 1947) dan Margaretha Angkuw (1948) untuk menempuh pendidikan di Sekolah Tinggi Teologia Jakarta. Hal ini menandakan bahwa GPI mulai memperhatikan kehadiran perempuan untuk ikut serta dalam melayani sebagai pendeta. Padahal Hervormed (Gereja Protestan di Belanda), yang menjadi induk GPI, masih belum menerima kehadiran perempuan sebagai pendeta. ${ }^{53}$ Menurut Pdt. (em) Hendrik Ongirwalu, GPIB lebih maju dari gereja di Belanda yang belum membolehkan perempuan sebagai pendeta. Hal itu berubah di Belanda tahun 1951. Dengan pentahbisan pendeta perempuan pertama di GPIB, yaitu:

Pdt. C. L. Manusama tahun 1953 dan langsung menjadi dosen di Sekolah Teologi Makassar, Pdt. M. Angkuw tahun 1954 dan langsung bekerja di Badan Diakonia sosial GPIB sebagai Sekretaris. Sesudah itu diserahkan ke DGI/PGI untuk melayani Rumah Sakit PGI Tjikini juga Pdt. M. Angkuw sebagai tenaga pelayan di Majelis Sinode GPIB yang kemudian berperan penting dalam pertumbuhan kaum Ibu dan pembentukan persatuan wanita dan Pdt. Henny L. Joseph tahun 1967 diutus GPIB menjadi dosen di STT Intim Makassar. Ketiganya tamatan STT Jakarta. Jumlah pendeta perempuan di

\footnotetext{
${ }^{53}$ Ibid.
} 
awal kemandirian antara tahun 19481970 hanya muncul 3 pendeta perempuan, karena pada waktu itu, semuanya masih studi terutama antara tahun 1966 sampai $1970 .^{54}$

Realitas menunjukkan bahwa kemampuan pendeta perempuan di awal kemandirian berperan sangat penting dan patut diperhitungkan sehingga pada periode 1974-1978, pendeta Margaretha Darma-Angkuw dipilih dalam persidangan sinode sebagai ketua I di struktur sinodal GPIB dan periode 1978-1982, pendeta Chatarina Louise Manupputy-Manusama terpilih sebagai ketua I di struktur sinodal GPIB. Penulis mengamati bahwa jejak rekam sejarah kepemimpinan ketiga pendeta perempuan pada periode awal kemandirian GPIB hendak menegaskan bahwa pendeta perempuan juga telah berkontribusi dalam kepemimpinan di sinodal, karena kesiapan dan kemampuan yang mereka miliki. Dengan berjalannya waktu, mereka berdua telah menunjukkan kemampuannya ketika berada dalam struktur di sinodal pada zamannya yang sangat kental dengan pengaruh patriarkat.

Dalam perjalanan waktu, menurut Pdt. (em) M. Meiske Mual-Loppies, pada tahun-tahun 1970 sudah ada pengakuan terhadap pendeta perempuan di GPIB akan tetapi dalam status kepemimpinan di sinodal masih sulit diterima pendeta perempuan sebagai fungsionaris. Periode itu, pendeta perempuan masih sedikit dan belum terlalu gigih memperjuangkan hakhaknya, karena pendeta laki-laki sangat mampu dan kuat. Pengertian mampu dan kuat disini adalah pendeta laki-laki

\footnotetext{
${ }^{54}$ Wawancara dengan pendeta $(\mathrm{em})$ Hendrik Ongirwalu, Jakarta, 18 Juli 2018.
}

secara kompetensi dan fisik. ${ }^{55}$

Sehubungan dengan hal di atas, menurut Pdt. (em) M. Meiske MualLoppies, pada tahun 1973, pendeta perempuan mulai memikirkan pemberdayaan pendeta perempuan secara struktural di lingkup jemaat terhadap pendeta perempuan yang menikah. Periode itu, pendeta perempuan memperjuangkan status menikahnya untuk tidak melepaskan jabatan (toga). Berkaitan dengan hal itu, terjadi diskriminasi terhadap perempuan karena ada aturan yang menegaskan bahwa pendeta laki-laki setahun melayani baru menikah, sedangkan pendeta perempuan harus dua tahun dulu melayani baru menikah, jikalau dia (pendeta perempuan) menikah maka lembaga langsung menon organikkan kependetaannya. ${ }^{56}$ Dalam periode itu, perjuangan pendeta perempuan melalui konsultasi pendeta perempuan yang pertama di Sukabumi, minim kehadiran pendeta perempuan, sehingga perjuangannya belum terakomodir dengan tepat dan baik. Kemudian konsultasi kedua di Cisarua, kehadiran pendeta perempuan sangat banyak, sehingga perjuangan mereka mulai diperhitungkan dan akhirnya tercapai bahwa pendeta perempuan yang menikah tetap sebagai pendeta ketua majelis jemaat. $^{57}$ Sehubungan dengan hal itu, maka dalam persidangan sinode 1978 di Kuningan Jakarta diputuskan bahwa pendeta perempuan diperlakukan sama dengan pendeta lakilaki. Pendeta perempuan yang menikah, baik dengan sesama pendeta maupun non pendeta dapat melayani dalam bidang-bidang pelayanan umum dan

\footnotetext{
${ }^{55}$ Wawancara dengan pendeta (em) M. Meiske Mual-Loppies, Bekasi, 18 Juni 2018. ${ }^{56}$ Ibid. ${ }^{57}$ Ibid.
} 
kategorial sebagai pendeta. ${ }^{58}$ Keputusan persidangan tersebut memperlihatkan adanya upaya untuk mensejajarkan kedudukan pendeta laki-laki dan pendeta perempuan.

Menurut Pdt. Meiske MualLoppies bahwa kepemimpinan pendeta perempuan sempat vakum di struktur kepemimpinan dari tahun 1982-2005 (4 periode) karena saat itu jumlah pendeta perempuan masih minim dan pendeta laki-laki sangat kuat dan berpotensi. Kemudian saat itu, pendeta perempuan masih belum siap masuk dalam struktur sinodal sebagai fungsionaris karena menurut mereka menjadi fungsionaris di struktur sinodal GPIB tidaklah mudah dan perjuangan pendeta perempuan untuk duduk di struktur sinodal sangatlah terbatas. ${ }^{59}$ Menurut Pdt. (em) M. Meiske Mual-Loppies, sesudah diakui kependetaannya di struktur sinodal dan jemaat, maka kembali pendeta perempuan berjuang untuk persamaan hak dengan pendeta laki-laki. Pada tahun 1990, pendeta perempuan diakui kependetaannya tetapi persamaan haknya masih dikesampingkan (tidak diberi tunjangan), walaupun pendeta perempuan menikah tetapi punya hak yaitu mendapat tunjangan suami dan anak. $^{60}$ Sehubungan dengan hal di atas, perjuangan pendeta perempuan mendapatkan respons dan diatur dalam tata gereja tentang hak pendeta perempuan yaitu mendapatkan tunjangan suami dan anak.

Dengan perkembanganperkembangan yang ada, persidangan sinode di Bali tahun 2005, pendeta

\footnotetext{
${ }^{58}$ Majelis Sinode GPIB, Ketetapan

Persidangan Sinode XII, Kuningan 1978

(Jakarta, 1978), 42.

${ }^{59}$ Ibid, wawancara dengan pendeta (em)

M. Meiske Mual-Loppies.

${ }^{60}$ Ibid.
}

perempuan kembali memperjuangkan supaya ada keterwakilan pendeta perempuan di struktur sinodal, karena mereka meyakini bahwa mereka memiliki kemampuan dan kapasitas di struktur sinodal. Perjuangan mereka disetujui oleh peserta sidang, terlihat bahwa semua peserta sidang memiliki cara berfikir yang sudah mulai berubah dan berproses ke arah kemajuan. ${ }^{61}$ Sehubungan dengan itu penulis mengamati bahwa cara pandang peserta sidang (baca: baik pendeta laki-laki, pendeta perempuan, penatua dan diaken) sudah mulai terbuka dengan menegaskan bahwa pendeta perempuan harus diberi kesempatan untuk memimpin di stuktur sinodal GPIB.

Pada tahun 2005 sampai dengan periode sekarang ini, pemahaman sebagian presbiter sudah mulai terbuka dan memberi peluang kepada pendeta perempuan di struktur sinodal sebagai fungsionaris GPIB. Akan tetapi budaya patriarki di sebagian jemaat GPIB yang masih dihayati oleh sebagian presbiter bisa mengakibatkan sulitnya pendeta perempuan menjadi ketua umum (pucuk pimpinan). Namun paling tidak dalam periode ini (2015-2020) GPIB sudah mempunyai beberapa pendeta perempuan yang memegang jabatan di lingkup sinode GPIB, baik itu sebagai ketua 3 maupun sekretaris umum dan sekretaris 1 .

(c) Pendeta Perempuan GPIB sebagai Agen Kepemimpinan Transformasional

Kepemimpinan transformasional lebih fokus pada kemampuan kepemimpinan dan membawa kepemimpinan yang baru dalam suatu perubahan dalam organisasi. Sejalan dengan hal itu, untuk pertama kalinya

\footnotetext{
${ }^{61}$ Ibid.
} 
dalam sejarah GPIB diadakan konsultasi pendeta wanita (perempuan) GPIB di Bina Warga Cipayung 25-28 Juni 1977. Alasan konsultasi itu diadakan adalah untuk membahas permasalahan karier pendeta wanita GPIB. $^{62}$ Alasan lainnya sehubungan dengan karier sesudah menikah, di mana majelis sinode berpegang pada ketentuan bahwa sesudah menikah maka seorang pendeta perempuan harus mengikuti suaminya dan bukan sebaliknya. Di mana sang suami dari pendeta perempuan itulah yang harus mengikuti langkah karier pelayanan sang istri di suatu jemaat GPIB. ${ }^{63}$ Hasil konsultasi menegaskan bahwa hal itu sama sekali bukan merupakan alasan untuk menghentikan karier sebagai pendeta jemaat bagi pendeta perempuan. Kesempatan untuk tetap melayani sebagai pendeta jemaat harus tetap terbuka. ${ }^{64}$ Realitanya bahwa GPIB sebagai lembaga telah mengupayakan langkah-langkah bagi pendeta perempuan untuk berkiprah dalam kepemimpinan struktural dan memfasilitasi pendeta perempuan untuk mencari solusi seputar masalah khas yang dihadapi mereka dalam pelayanan di GPIB melalui konsultasi pendeta. Hal itu sejalan dengan pendapat S.W. Lontoh dan Hallie Jonathans bahwa GPIB sebagai lembaga tidak pernah membedakan secara diskriminatif hak seorang pendeta perempuan dibandingkan dengan pendeta lakilaki. ${ }^{65}$

Dengan dilaksanakannya konsultasi pendeta perempuan tahun 1977, penulis melihat sikap GPIB sebagai lembaga semakin jelas terhadap 199.

${ }^{62}$ Ibid, S.W. Lontoh \& Hallie Jonathans,

\footnotetext{
${ }^{63}$ Ibid.

${ }^{64}$ Ibid, S.W. Lontoh \& Hallie Jonathans.

${ }^{65}$ Ibid.
}

persoalan pendeta perempuan dalam karier pelayanannya, itu berarti implikasi praktisnya memberikan peluang kepada pendeta perempuan di GPIB sebagai agen kepemimpinan transformasional. Dari situlah awal bangkitnya pendeta perempuan di GPIB sebagai agen transformasi bagi dirinya dan kepemimpinannya. Pendeta perempuan di GPIB sebagai agen yang terus-menerus berkarya dalam membawa suatu perubahan yang sangat penting bagi perkembangan pelayanan GPIB di masa mendatang.

Menurut Margie I. Ririhena-de Wanna, seorang pendeta GPIB, menyatakan dalam konteks perempuan GPIB di era baru jemaat misioner, spiritualitas perempuan yang peduli dan menggerakan perempuan memasuki realitas bergereja yang mengarahkan pada misi dengan semangat kesalehan, yang memotivasi pendeta perempuan aktif dan terlibat langsung dengan kegiatan-kegiatan pelayanan dan kesaksian (PELKES GPIB) di berbagai wilayah. ${ }^{66}$ Betapa spirit GPIB sebagai lembaga dengan program-program pelayanan kesaksian (pelkes) sinodal bersama pemerintah untuk membangun sarana pendidikan, sarana air bersih, kesehatan, sarana transportasi dan sarana peribadahan yang layak dan baik untuk fokus pada pelayanan mereka. Selain itu juga dengan program-program anak asuh di wilayah pos-pos pelkes GPIB dan memotivasi beberapa anak-anak asuh itu untuk studi lanjut ke perguruan tinggi melalui komitmen donatur (untuk menjadi orang tua asuh). Apabila memperhatikan program-program sinodal GPIB yang disebutkan di atas, hal itu berpengaruh terhadap spirit melayani pendeta perempuan untuk

\footnotetext{
${ }^{66}$ Ibid, Margie I. Ririhena-de Wanna,
} 
mewujudkan dirinya sebagai agen kepemimpinan yang transformasional. Sejalan dengan hal di atas, dalam buku Bahtera Guna Dharma GPIB menegaskan bahwa dalam membangun jemaat misioner, GPIB mengembangkan dan membina pola seperti datang, pergi dan mengembang, yaitu membangun relasi yang relevan dan komunikatif antara Injil dan dunia dengan tujuan membangun kehidupan bersama yang sejahtera. ${ }^{67}$ Hal itu juga berimplikasi secara praktis pada pendeta perempuan sebagai agen kepemimpinan transformasional di lingkup struktural dan jemaat yang ada di lingkup GPIB.

Margie I. Ririhena-de Wanna mengutip salah satu pendapat dari inspirator pendeta perempuan GPIB yaitu pendeta Margaretha DarmaAngkuw bahwa pendeta perempuan sebagai pelaksana misi gereja tanpa dinding, artinya menyampaikan kabar baik bukan hanya melalui khotbah di dalam gedung gereja, tetapi melalui beragam kegiatan nyata bersama warga jemaat dan warga masyarakat agar melaluinya kegiatan misi Allah terus dikerjakan. ${ }^{68}$ Pendeta perempuan dipanggil dan diutus untuk melayani dan memimpin gereja secara bersama. Kebersamaan itu bukan atas dasar sukarela atau terpaksa, tetapi karena misi Kristus itu yang satu dan mempersatukan para pejabat gerejawi. Kebersamaan itu harus terwujud dalam tindakan, yaitu: berjalan, bergumul, bermusyawarah, bekerja dan berbuat serta mempunyai pengalaman bersama mengisi persekutuan untuk melayani dan bersaksi.

\footnotetext{
${ }^{67}$ Ibid, S.W. Lontoh dan Hallie Jonathans, 78-79.

${ }^{68}$ Ibid, Margie I. Ririhena-de Wanna, 189.
}

\section{Metode Penelitian}

Metode Penelitian ini adalah metode penelitian kualitatif deskriptif. Menurut Lexy J. Moleong, penelitian kualitatif adalah penelitian yang bertujuan memahami fenomena yang dialami oleh subjek penelitian. Misalnya perilaku, persepsi, motivasi, tindakan, dan lain sebagainya, secara holistik dengan cara deskriptif dalam suatu konteks khusus yang alami tanpa ada campur tangan manusia dan dengan memanfaatkan secara optimal berbagai metode ilmiah yang biasa atau lazim digunakan. $^{69}$ Penelitian kualitatif menekankan pada quality atau hal terpenting dari suatu barang atau jasa, berupa kejadian, fenomena, dan gejala sosial, yang mana makna daripadanya dapat dijadikan pelajaran berharga bagi pengembangan teori. Proses penelitian ini mencakup perihal membuat pertanyaan penelitian dan prosedur yang bersifat sementara, mengumpulkan data, menganalisis data dan membangun data ke dalam tema dan selanjutnya memberikan interpretasi terhadap makna suatu data. $^{70}$

Dalam penelitian kualitatif, metode yang biasa dimanfaatkan atau digunakan adalah: studi pustaka, wawancara, observasi dan dokumentasi. $^{71}$ Adapun instrumen penelitian yang digunakan dalam penelitian ini adalah: pedoman wawancara dan pedoman observasi. Sampel dalam penelitian ini ditentukan dengan menggunakan teknik purposive sampling (sampel bertujuan), di mana

\footnotetext{
${ }^{69}$ Lexy. J. Moleong, Metode Penelitian Kualitatif (Bandung: Remaja Rosdakarya, 2010), 6.

${ }^{70}$ Sugiyono, Cara Mudah Menyusun

Skripsi, Tesis, dan Disertasi (Bandung:

Alfabeta, 2013), 228.

${ }^{71}$ Ibid, Lexy. J. Moleong, 5.
} 
seseorang dapat dijadikan sampel didasarkan pada tujuan tertentu. ${ }^{72}$ Penelitian ini dilakukan di kantor Majelis Sinode GPIB, jalan Medan Merdeka Timur, Jakarta dan informan lainnya yang dilakukan di kantor dan di rumah informan tersebut yang ada di wilayah Jakarta dan Bekasi. Penelitian dimulai dari bulan Februari 2018 sampai dengan Juni 2018. Analisa data dalam penelitian kualitatif dilakukan dalam tiga tahap, yakni sebelum memasuki lapangan, selama di lapangan dan setelah selesai di lapangan. ${ }^{73}$ Tahapan aktivitas analisis yakni: 1) pengumpulan data, 2) reduksi data, 3) penyajian data, 4) kesimpulan dan verifikasi.

\section{Temuan Penelitian dan}

\section{Analisis}

\subsection{Temuan Penelitian}

Dalam penelitian yang dilakukan penulis, ditemukan beberapa hal sebagai berikut:

- GPIB dalam hal kepemimpinan tidak melihat laki-laki atau perempuan, karena perempuan dan laki-laki diciptakan menurut gambar dan rupa Allah. Syarat menjadi pemimpin di GPIB adalah dapat memenuhi syarat kualitatif dan administratif. Tugas pendeta perempuan sama dengan pendeta laki-laki dan tidak ada perbedaan. Pendeta perempuan sama pentingnya dengan pendeta lakilaki.

- Sentuhan-sentuhan feminis dalam kepemimpinan perempuan itu garis linear bukan garis komando. Kepemimpinan pendeta perempuan

${ }^{72}$ Sugiyono, Metode Peneltian

Kuantitatif, Kualitatif dan $R \& D, D$ (Bandung: Alfabeta, 2016), 219.

${ }^{73}$ Sugiyono, Metode Penelitian Manajemen (Bandung: Alfabeta, 2014), 336. lebih berwarna. Artinya Pemimpin yang membawa perubahan, dia harus membuka diri, mau mendengar, dalam dirinya harus ada ruang bersama dengan Tuhan. Langkah GPIB sebagai lembaga terus menjadi mitra untuk pendeta perempuan memberdayakan dirinya sebagai agen transformatif.

- Kehadiran pendeta perempuan bisa menyeimbangkan dominasi kaum laki-laki di tengah-tengah ruang publik, sehingga pelayananpelayanan itu pun juga lebih bisa dikerjakan dengan lebih sensitif terhadap kebutuhan-kebutuhan, persoalan-persoalan dan perasaanperasaan keperempuanan itu sendiri.

- Kepemimpinan pendeta perempuan sangat penting, karena ada sisi yang positif dari diri seorang pendeta perempuan yang sangat dibutuhkan oleh jemaat maupun lembaga.

- Kemampuan dari sebagian pendeta perempuan dalam berorganisasi masih cenderung lemah.

- Pendeta perempuan menjadi fungsionaris majelis sinode GPIB harus dikenal orang (artinya berkiprah di jemaat, mupel, sinodal dan oikumene).

- Secara umum kolegialitas cenderung menunjukkan dengan teman seangkatan vikariat dan almamater. Kolegialitas masih harus dibangun secara terus-menerus.

- Fungsionaris majelis sinode GPIB telah berkunjung ke kampuskampus teologi dan mengumpulkan anak-anak GPIB yang direkomendasikan belajar di sekolah teologi yang diakui oleh GPIB (4 sekolah teologi) dengan tujuan mengarahkan dan memberi pendampingan bagi para mahasiswa untuk memahami dan mengetahui tentang apa itu GPIB dan tantangan 
yang akan dihadapi jikalau menjadi pendeta GPIB. Sehubungan dengan hal itu, siapa pun menjadi pemimpin baik perempuan dan laki-laki sudah melalui jenjang pelatihan dasar kepemimpinan (PDP) di jemaat.

- Periode-periode sebelumnya menunjukkan bahwa realita di lapangan, sebagian jemaat-jemaat, khususnya di pos-pos pelayanan dan kesaksian

(PELKES)

kecenderungan menolak pendeta perempuan karena cara pandang di sebagian jemaat masih patriarkat dan bias gender. Masih ada sebagian jemaat memiliki pola pemahaman bahwa perempuan itu lemah, perempuan itu hanya diruang domestik dan perempuan itu kelas nomor dua. Dalam periode ini, majelis sinode telah melakukan pendekatan dan langkah-langkah yang sudah ditempuh melalui pembinaan-pembinaan.

- Pembelajaran dan pembinaan tentang kepemimpinan sudah baik akan tetapi di lapangan terkendala karena budaya person maupun budaya organisasi lokal (di sebagian jemaat) yang seringkali kurang memberi ruang kepada para pendeta untuk belajar banyak hal dan mengikuti pelatihan dan pembinaan.

- Sesungguhnya jabatan ketua umum bukanlah yang tertingi dalam GPIB. Ketua umum dan lainnya hanyalah pembidangan. Namun, dalam praktiknya ketua umum dilihat sebagai jabatan yang tertinggi. Budaya patriarki yang masih dihayati oleh banyak presbiter bisa mengakibatkan sulitnya pendeta perempuan menjadi ketua umum (pucuk pimpinan). Namun paling tidak GPIB sudah mempunyai beberapa pendeta perempuan yang memegang jabatan di lingkup sinode GPIB, baik itu sebagai ketua 3 maupun sekretaris umum dan sekretaris 1 .

\section{Analisa}

\subsection{Tinjauan Teologis}

Peran tokoh-tokoh perempuan dalam Perjanjian Lama dan Perjanjian Baru sudah dipahami, dijiwai dan dihayati dengan sungguh-sungguh oleh pendeta perempuan akan tetapi realitanya kecenderungan di lapangan rasa kepedulian masih kurang dalam diri sebagian pendeta perempuan sehingga kalau mau jujur hal itulah yang mengakibatkan tumbuhnya bias kepentingan, minimnya rasa kolegialitas, tumbuhnya almamaterisme dan sukuisme. Dengan demikian, bagi penulis semua peran tokoh-tokoh perempuan dalam Perjanjian Lama dan Perjanjian Baru dapat menjadi teladan dan menginspirasi bagi pendeta perempuan dan yang terpenting secara pribadi belajar dengan membuat refleksi diri berdasarkan Firman Tuhan.

\subsection{Tinjauan Pedagogis}

Perempuan mempunyai pengalaman, mempunyai citra diri dan belajar mengatasi masalahnya. Hal ini menarik, jikalau perempuan mampu memimpin jika diberi peluang untuk belajar yang khas perempuan. Artinya pendekatan seorang perempuan akan membuka pembelajaran baru yang khas perempuan. Pembelajaran yang khas perempuan salah satunya mendengar. Hal itu menjadi suatu pertanda bahwa kepemimpinan pendeta perempuan harus mampu membuka jendela kehidupan orang lain.

Jikalau tidak diberikan peluang untuk belajar maka dipastikan pendeta perempuan tidak mempunyai akses untuk mengembangkan dirinya. Seharusnya diberikan akses pendidikan 
yang sama baik laki-laki dan perempuan untuk mengembangkan diri. Kalau tidak diberikan akses melalui pendidikan, maka peran perempuan tidak akan seimbang dengan laki-laki. Bahkan tidak tampak adanya harmonisasi dalam kepemimpinan baik dilingkup sinodal dan jemaat. Mengacu hal di atas, aspek pendidikan sangat penting bagi kepemimpinan pendeta perempuan. Dengan diberikannya peluang dan kesempatan kepada perempuan untuk studi yang seluasluasnya, maka akses komunikasi dengan dunia luar akan terbangun dengan baik dan kualitas didiknya akan lebih maju. Pedagogis bagi kepemimpinan pendeta perempuan adalah dia harus belajar mempersiapkan diri dan mengembangkan diri. Karena tantangannya di sinodal/jemaat masih menunjukkan produk masyarakat patriarkat. Jadi pendeta perempuan harus lebih didorong/dimotivasi untuk terus menggali potensi diri melalui pendidikan.

\subsection{Kepemimpinan Pendeta Perempuan di Lingkup Sinodal GPIB}

Penulis mengamati bahwa tidak dapat disangkal struktur masyarat secara umum kecenderungan patriarki, mengakibatkan peran perempuan hanya di ruang domestik dan laki-laki di ruang publik. Sejalan dengan itu, apabila melihat perkembangan kepemimpinan pendeta perempuan GPIB sampai hari ini, budaya patriakat sangat mempengaruhi kepemimpinan pendeta perempuan, kesannya membatasi peran perempuan dalam ruang publik. Hal itu juga tampak bahwa dominasi kaum laki-laki masih dominan di ruang publik.

Untuk menjawab hal di atas, solusi pertama, penulis sependapat dengan pandangan dari feminis pembaharuan yang memberi kesempatan kepada kaum perempuan untuk menggunakan potensinya. Dalam masyarakat yang patriarkat, pembagian tugas menurut jenis kelamin itu membatasi kebebasan perempuan. ${ }^{74}$ Artinya perempuan hanya dapat memainkan beberapa bagian peran yang cocok dengan kedudukannya, misalnya perempuan selalu identik dengan peran sekretaris dan bendahara. Kesannya, mereka berfungsi seperti separuh manusia. Maka harus diberikan peluang bagi perempuan di semua peran yang ada. Sehubungan dengan hal itu, pembaharuan dapat dicapai secara individual (baca para presbiter). Maksudnya pembaharuan individual di mana pola pemahaman presbiter yang dipengaruhi budaya patriarkat diarahkan dan dibina tentang aturan yang termuat dalam tata gereja yang telah disepakati bersama harus benarbenar dipahami, terlebih lagi pembinaan-pembinaan dan pelatihanpelatihan tentang kepemimpinan harus berkesinambungan di jemaat supaya pemahaman mereka di ubahkan.

Sejalan dengan itu, solusi kedua, penulis mengusulkan model emansipasi yang ditawarkan oleh feminis emansipasi bahwa peran perempuan seharusnya dilepaskan dari kuk tradisi yang ada. Dengan kata lain kaum perempuan harus lepas dari pengaruh peran tradisional patriarki. Jadi pembatasan kedudukan dan partisipasi (kontribusi) perempuan dalam kepemimpinannya harus dimulai dari lingkup individu (baca pendeta perempuan dan pendeta laki-laki). ${ }^{75}$ Tugas emansipasi ini juga merupakan

\footnotetext{
${ }^{74}$ Aya Susanti, Feminisme Radikal, Studi Alkitabiah (Bandung: Yayasan Kalam Hidup, 2008), 139.
} 
tugas gereja yang kontekstual yang bermaksud mewadahi gerakan-gerakan kesetaraan gender. Karena itu pengaruh gerakan feminis turut memberi arah pada gerak perempuan GPIB sebagai pelaksana missio Dei.

Sehubungan dengan hal di atas, menurut Pdt. Margie I. Ririhena de Wanna, budaya patriaki yang berkembang kuat seringkali cenderung memiliki kekuatan untuk memasukkan unsur-unsur patriaki itu dalam hampir seluruh sistem bergereja (baca: GPIB). Pendekatan struktural/organisasi, penggunaan istilah-istilah dan model kepemimpinan patriaki sangat kuat muncul dalam hampir seluruh hasil keputusan gerejawi yang diambil. Karena itu menurutnya untuk solusi hal di atas adalah dengan pendekatan teologi feminis sebagai salah satu pendekatan dalam menyoal kepemimpinan pendeta perempuan di GPIB. $^{76}$ Ada banyak model kepemimpinan yang muncul sepanjang sejarah gereja tetapi model kepemimpinan feminis menjadi pendekatan yang menarik dalam merawat kebersamaan dan membangun kolegialitas yang menjadi konteks GPIB.

Kepemimpinan perempuan tidak sama persis dengan kepemimpinan lakilaki. Kepemimpinan perempuan itu harus lebih pada kesadaran untuk berkontribusi. Menjadi seorang pemimpin di lingkup struktural GPIB tidaklah gampang dan mudah seperti kita membalikan telapak tangan, akan tetapi dibutuhkan seorang pemimpin yang memiliki spiritualitas yang baik, kesiapan hati, kerendahan hati dan membangun kompetensi diri (kognitif, afektif dan psikomotorik).

${ }^{76}$ Ibid, wawancara dengan pendeta Margie. I. Ririhena-de Wanna, Jakarta, 16 Juli 2018.
Periode ini jauh lebih dinamis dengan berbagai temuan yang lebih baik seperti digambarkan oleh para informan dalam penelitian ini. Berbagai tantangan pun makin kompleks dan rumit. Itu berarti bahwa kepemimpinan di periode ini, banyak melibatkan kaum perempuan di ruang publik. Sekarang terpulang kepada kaum perempuan sendiri untuk mengisi peluang-peluang tersebut, bukan untuk menyaingi kaum laki-laki, melainkan untuk saling melengkapi, yang terpenting perempuan harus mengenal identitas dirinya (kemampuannya), bukan sebagai tiruan dari laki-laki, artinya perempuan dalam mengemban tugas dan pelayanannya haruslah yang khas perempuan. Janganlah perempuan berubah menjadi laki-laki hanya supaya diakui. Dengan demikian jangan dibangun dikotomi kepemimpinan laki-laki dan perempuan artinya kepemimpinan itu mestilah ditempatkan di bawah kepemimpinan Yesus Kristus.

\section{Kesimpulan}

\subsection{Tinjauan Teologis}

Secara teologis kepemimpinan pendeta perempuan di GPIB dibangun berdasarkan Alkitab bahwa perempuan dan laki-laki diciptakan segambar dengan Allah (Kej. 1:27). Artinya lakilaki dan perempuan adalah gambar Allah yang diciptakan setara dan sederajat. Implikasinya bahwa pemimpin pendeta perempuan dan pemimpin pendeta laki-laki tidak ada perbedaan dalam hal kepemimpinan di lingkup sinodal GPIB. Sehingga di GPIB tidak mengistimewakan gender. GPIB sebagai lembaga sudah sangat maju dan terbuka memberikan peluang untuk perempuan memimpin di lingkup struktural sinodal GPIB. Terbukti dari awal kemandirian GPIB, pendeta perempuan telah menunjukkan 
perannya di struktural tahun 1974-1978 (Pdt. Margaretha Darma-Angkuw sebagai ketua 1) dan tahun 1978-1982 (Pdt. Chatarina Louise ManupputyManusama sebagai ketua I) dan di periode sekarang $\mathrm{MS} \mathrm{XX}$, pendeta perempuan yang memegang jabatan di lingkup sinode GPIB, baik itu sebagai ketua 3 maupun sekretaris umum dan sekretaris 1. Hal ini menunjukkan bahwa GPIB sudah sangat terbuka dan memberi kesempatan seluas-luasnya kepada pendeta perempuan untuk berkiprah di ruang publik dan sejarah perkembangan kepemimpinan pendeta perempuan di GPIB di periode awal kemandirian sampai dengan periode saat ini mengalami kemajuan yang significant dan peningkatan yang terusmenerus.

\subsection{Tinjauan Pedagogis}

Secara Pedagogis, GPIB sebagai lembaga terbuka dan memberikan peluang yang sangat luas kepada pendeta perempuan untuk membangun dan mengembangkan dirinya melalui pendidikan, pelatihan dan pembinaan. GPIB menganut ajaran Calvin yang menyatakan bahwa gereja adalah umat yang bertugas belajar dan mengajar. Artinya pendeta perempuan harus memotivasi dirinya untuk merespons peluang-peluang yang telah ada melalui program-program sinodal untuk belajar membangun kompetensi dirinya dan kepemimpinannya melalui studi formal maupun informal. Pedagogis dalam hal kepemimpinan di GPIB mengacu pada bidang Pembinaan dan Pengembangan Sumber Daya Insani (PPSDI). Contohnya studi formal, dalam periode ini, banyak pendeta perempuan dan pendeta laki-laki diberikan peluang untuk studi lanjut S2 dan S3 diberbagai perguruan tinggi. Contoh studi informal, yaitu terlihat dalam upaya
GPIB untuk mulai kembali memberikan pembinaan tingkat dasar, lanjutan, madya bahkan pra emeritus kepada para pendeta GPIB baik laki-laki maupun perempuan.

\subsection{Kepemimpinan Pendeta Perempuan di Lingkup GPIB}

Awal kemandirian GPIB sebagai lembaga sampai dengan periode ini, GPIB sudah sangat maju, terbuka dan memberi peluang bagi pendeta perempuan untuk berkiprah di ranah struktural sinodal maupun struktural jemaat. Sejarah juga mengisahkan bahwa pendeta perempuan sebagai pelaku sejarah telah berperan di ruang publik dan domestik. Peran domestik maupun peran publik sudah ikut mempengaruhi perubahan pada kepemimpinan di GPIB. Meskipun dalam kepemimpinan pendeta perempuan banyak tantangan, tetapi pendeta perempuan GPIB telah mempengaruhi gerak menggereja menurut konteksnya. GPIB dalam kepemimpinannya menganut sistem presbiterial sinodal yang diletakkan oleh Calvin. Presbiterial sinodal yang dianut oleh GPIB adalah sebuah konsep kepemimpinan yang kolektif kolegial, artinya bahwa semua berjalan bersama, diputuskan bersama, dilaksanakan bersama dan dievaluasi bersama. Implikasinya pendeta perempuan sebagai presbiter GPIB harus menjunjung tinggi kebersamaan dalam tugas panggilan dan pengutusannya di struktur sinodal maupun di struktur jemaat.

Spirit GPIB sebagai lembaga sudah sangat maju dan terbuka memotivasi pendeta perempuan sebagai pemimpin yang transformatif, artinya pemimpin yang terus-menerus membawa perubahan yang baik dalam pelayanan, di mana pendeta perempuan 
harus menjadi teladan untuk membangun jaringan yang merajut kebersamaan dan keterpaduan untuk saling membekali diri dalam rangka menyaksikan Kemuliaan Nama Tuhan dan keluhuran kemanusiaan. Untuk membangun kepemimpinan perempuan yang transformatif harus dibangun berdasarkan Alkitab (Firman Tuhan), mempersiapkan diri dengan berkualitas, mampu memperlengkapi diri dengan pendidikan, pelatihan dan pembinaan.

\section{Daftar Pustaka}

\section{Buku}

LAI, Alkitab, Jakarta: LAI, 2005

Abineno J. I. C. H, Garis-Garis Besar Hukum Gereja: dalam Wairata, Kepemimpinan menurut paham GPIB, Jakarta, 2003.

Bashin Kamila, Menggugat Patriarki: Pengantar tentang Persoalan Dominasi terhadap Kaum Perempuan, Yogyakarta: Bentang Budaya, 1996.

Beek Aart Van, Pendampingan Pastoral, Jakarta: BPK Gunung Mulia, 2001.

Chuzaifah Yuniyanti, Negosiasi Hak Kepemimpinan Perempuan di Ranah Publik: Perspektif Theologi dan HAM Perempuan, Dalam Kajian Titik Temu: Kepemimpinan Perempuan dari perspektif Teologi dan HAM Part 2, Jakarta, 06 Juni 2018.

Darmawijaya St, Perempuan dalam Perjanjian Lama, Yogyakarta: Kanisius, 2003.

Fatimah Siti \& Wirdanengsih, Gender dan Pendidikan Multikultural, Jakarta: Kencana, 2016.

Fakih Mansour, Analisa Gender dan Transformasi Sosial, Yogyakarta: Pustaka Pelajar 2002.

Haryono, Jurnal Teologi dan Misi: Pendidikan berkualitas di Geneva, 2012.
Hemmes Anne, Perubahan Peran Laki-laki dan Wanita dalam Gereja dan Masyarakat, Jakarta: BPK Gunung Mulia dan Yogyakarta: Kanisius, 1992.

Hehanussa Josef M.N, Masih Ada banyak Pekerjaan Rumah untuk Kita, dalam Suarakanlah Kebenaran, Menyikapi Persoalan dalam Tubuh GPIB, Jakarta: Komunitas Peduli Reformasi GPIB, 2015.

Hocking David, Rahasia Keberhasilan Seorang Pemimpin, 7 Hukum Kepemimpinan Rohani, Yogyakarta: Yayasan ANDI, 1991.

Lako Andreas, Kepemimpinan dan Kinerja Organisasi: Isu, Teori dan Solusi, Yogyakarta: Amara Books, 2004.

Lontoh S. W. \& Hallie Jonathans, Bantera Guna Dharma GPIB, Jakarta: BPK Gunung Mulia, 2014.

Maitimoe A, Kepemimpinan yang Melayani, dalam Ministrium Buletin Teologi Gereja, vol. 2, nomor 2, Jakarta, Januari-Juni 2003.

Mantik Maria Josephine, Mengapa Perempuan dipersulit Menjadi Pemimpin, Saat Perempuan Menjawab Panggilan dan Pengutusan Tuhan, Jakarta: PT Grasindo, 2012.

Maitimoe D. R, Membina Jemaat Misoner, Jakarta: BPK Gunung Mulia, 1984.

Moleong Lexy. J, Metode Penelitian Kualitatif, Bandung: Remaja Rosdakarya, 2010.

Ongirwalu Hendrik, Sejarah Gereja Protestan di Indonesia, jilid 1, Jakarta: Badan Pekerja Harian Gereja Protestan di Indonesia, 2005.

Pamungkas Sutan G, Jurus Ampuh Menjadi Pemimpin Dahsyat dan Fenomenal, Yogyakarta: Araska, 2012.

Rantung Joys Anneke, Resolusi Konflik dalam Organisasi; Kajian dari Perspektif Pendidikan Perdamaian terhadap Kasus Konflik di Lembaga Pendidikan, Jakarta: BPK Gunung Mulia, 2017. 
Ririhena Margie I. de Wanna, Merajut Identitas Eklesiologi di Seputar Konflik Lombok, Jakarta: BPK Gunung Mulia, 2016.

Sallis Edward, Total Quality Management in Education, Manajemen Mutu Pendidikan, Yogyakarta: IRCiSoD, 2012.

Siagian Sondang P, Teori dan Praktik Kepemimpinan, Jakarta: Rineke Cipta, 2003.

Singgih E.G, Implikasi Gender dalam Lembaga Pendidikan Teologi, dalam Berikanlah Aku Air Hidup itu, bahan sumber-sumber studi Gender, hasil Konsultasi dan Lokakarya Wanita Berpendidikan Teologi Persetia dan Biro Pelayanan, Jakarta: PERSETIA, 1997.

Sugiyono, Cara Mudah Menyusun Skripsi, Tesis, dan Disertasi, Bandung: Alfabeta, 2013. , Metode Peneltian Kuantitatif, Kualitatif dan $R \& D$, Bandung: Alfabeta, 2016. , Metode Penelitian Manajemen, Bandung: Alfabeta, 2014.

Susanti Aya, Feminisme Radikal, Studi Alkitabiah, Bandung: Yayasan Kalam Hidup, 2008.

Tomatala Yakob, Kepemimpinan yang Dinamis, Jakarta: Leadership Foundation, 1997.

Wairata C, "Kepemimpinan: Suatu Tinjauan Kepejabatan dari Perspektif Ekklesiologi menurut paham GPIB", dalam Ministrium Buletin Teologi Gereja Volume 2, Nomor 2, Januari-Juni 2003.

Waney Paul, Peranan Wanita Berpendidikan Teologi di Perkotaan, dalam Berikanlah Aku Air Hidup itu: Bahan Sumber-sumber Studi Gender, hasil Konsultasi dan Lokakarya Wanita Berpendidikan Teologi Persetia dan Biro Pelayanan, Jakarta: PERSETIA, 1997.

Wiryana Bernadine R, M.S.W \& Susilo Supardo, Kepemimpinan: Dasar-
Dasar dan Pengembangannya, Yogyakarta: Andi, 2005.

Wuwungan O. E. Ch, Pemahaman Alkitab dan Warga Gereja, Jakarta: Pustaka Sinar Harapan, 1997.

\section{Dokumen GPIB}

Majelis Sinode GPIB, Keputusankeputusan Persidangan Sinode GPIB ke X Bandungan, Ambarawa, Jakarta, 1970.

, Ketetapan Persidangan Sinode XII, Jakarta, 1978.

, Ketetapan Persidangan Sinode XIII, Jakarta, 1982.

, Ketetapan Persidangan Sinode XV, Jakarta, 1990.

, Ketetapan Persidangan Sinode XVIII, Jakarta, 2005.

, Ketetapan Persidangan Sinode XIX, Jakarta, 2010.

, Ketetapan Persidangan Sinode XX, Jakarta, 2010.

, Menggumuli Teologi Calvin, Pemahaman Iman GPIB dan Keindonesiaan, Gereja dan Budaya, Prosiding Konsultasi Teologi GPIB, 2017. 